\title{
OBRIGAÇÕES EMPRESARIAIS NO NOVO CÓDIGO CIVIL
}

\author{
Ligia Paula Pires Pinto Sica ${ }^{1}$
}

CORPORATE LAW AND THE NEW BRAZILIAN CIVIL CODE

\section{RESUMO}

TEndo em Vista a promulgação do novo Código Civil BRASILEIRO, QUE REÚNE DISPOSITIVOS QUE REVOGAM O ANTIGO Código CIVIL DE 1916 E A MAIORIA dOS CAPÍTULOS DO Código COMERCIAL DE 1850, UNIFICANDO-OS, É IMPORTANTE QUE SE FRISE QUE REMANESCE A DIFERENCIAÇÃO ENTRE AS MATÉRIAS DE DIREITO CIVIL E COMERCIAL, DE ACORdO COM SUAS LÓGICAS PECULIARES.

SENDO ASSIM E TENDO O NOVO CÓdIGO INTRODUZIDO DIVERSAS NORMAS DE CARÁTER GERAL, ESTE TRABALHO PRETENDE DISCUTIR O PAPEL DO JUIZ E DA JURISPRUDÊNCIA NA APLICAÇÃO DESSAS NORMAS DE MANEIRA CASUÍSTICA, DANDO-LHES TRATAMENTOS DISTINTOS DE ACORDO COM OS FATOS APRESENTADOS EM JUÍZO, DE FORMA A MANTER A AUTONOMIA DAS ÁREAS DO DIREITO MENCIONADAS E GARANTIR AOS AGENTES ECONÔMICOS O GRAU DE SEGURANÇA E PREVISIBILIDADE NECESSÁRIO ÀS SUAS ATUAÇÕES NO MERCADO.

\section{PALAVRAS-CHAVE}

UNIFICAÇÃO, INTERPRETAÇÃO, BOA-FÉ, CLÁUSULA GERAL, JURISPRUDÊNCIA

\author{
ABSTRACT \\ IN REGARD OF THE ENACTMENT OF THE NEW BRAZILIAN CIVIL \\ CODE, THAT UNIFIES THE ISSUES TREATED IN THE OLD CIVIL \\ CODE FROM 1916 AND ON THE MAJORITY OF THE CHAPTERS OF \\ THE COMMERCIAL CODE FROM 1850, IT'S IMPORTANT TO INSIST \\ THAT THE DIFFERENCES BETWEEN THE CIVIL AND COMMERCIAL \\ LAW REMAINS, ACCORDING TO THEIR PECULIAR LOGICS. \\ AS IT IS, AND AS THE NEW CODE BROUGHT SEVERAL RULES \\ OF GENERAL CHARACTER, THIS PAPER INTENDS TO DISCUSS \\ THE ROLE OF THE JUDGE AND JURISPRUDENCE IN THE CIVIL \\ LAW SYSTEM, BY INTERPRETATING THOSE RULES IN A \\ CASUISTIC MANNER, GIVING THEM DIFFERENT TREATMENTS, \\ ACCORDING TO THE PRESENTED FACTS DURING LITIGATION, \\ IN A WAY TO MAINTAIN THE AUTONOMY OF THE LAW AREAS \\ MENTIONED ABOVE AND GUARANTEE TO THE ECONOMIC AGENTS \\ THE LEVEL OF CERTAINTY AND PREVISIBILITY, NEEDED TO \\ EXERCISE THEIR ACTIVITIES IN THE MARKET.

\section{KEYWORDS} \\ UNIFICATION, INTERPRETATION, GOOD FAITH, GENERAL \\ CLAUSE, JURISPRUDENCE
}

"Havendo duvida sobre a intelligencia e força de hum Contracto mercantil, deve-se interpretar a mente dos contrahentes segundo o uso, ou Estatuto da Praça e lugar em que se fez o mesmo contracto; e bem assim o Juizo dos Commerciantes costumados a praticar essa especie de negocio, ainda que aliás as palavras do trato, ou escripto diversamente signifiquem: pois sempre a boa fé e o estylo mercantil he que deve prevalecer e reger, e não o estreito significado dos termos e menos ainda as intelligencias cavillosas e contrarias ao verdadeiro espirito do contracto” 
(José da Silva Lisboa, o Visconde de Cayru, Principios de direito mercantil e leis da Marinha, Rio de Janeiro: Typographia Acadêmica, 1874, t. II, p. 471).

\section{Delimitação do Tema}

Iniciei este trabalho a partir de duas questões: (i) a promulgação do Código Civil brasileiro, que unifica grande parte das disciplinas de Direito Comercial e Direito Civil, causará falta de segurança jurídica para a celebração de negócios empresariais? e (ii) qual o papel do aumento dos poderes do juiz e a importância da jurisprudência neste cenário, especialmente diante da inserção de cláusulas gerais no referido diploma legal?

Sem dúvida, essas questões partiram da minha intuição de que a jurisprudência se prestaria a pautar a interpretação dos novos artigos, embora eu não tenha me proposto a provar essa assertiva. Comecei a minha pesquisa teórico-doutrinária e, depois, jurisprudencial (que, a meu ver, não deixa de ser teórica), a partir de um índice que pouco tem a ver com o sumário acima. Não queria convencer nem ser convencida de uma única resposta, mas adianto: a pesquisa levou-me, aos poucos, a um convencimento acerca de respostas às duas perguntas acima descritas e à reformulação delas.

Comecei os trabalhos pelo estudo do novo Código, de alguns artigos que traziam cláusulas gerais e da doutrina acerca dos institutos de Direito Obrigacional que elas representavam. Contudo, percebi que aquele cabedal não responderia satisfatoriamente às perguntas primeiramente formuladas e sobre o papel do juiz e da jurisprudência na interpretação dos artigos no contexto delimitado (relações empresariais).

Assim, sem almejar traçar panorama prévio acerca das regras de interpretação do Direito e do Direito Empresarial (ou Direito Comercial, aqui e adiante utilizados como sinônimos), passei a buscar "como" explicitar a relação entre a interpretação dos novos dispositivos do Código Civil quanto às obrigações advindas de relações empresariais e a jurisprudência. Isso porque, como alguns dos dispositivos do Código Civil são propositalmente vagos (cláusulas gerais), a um certo ponto, passei a crer que a jurisprudência demonstrará ter um papel importantíssimo na construção ou confirmação do já construído, ao atuar como base sólida para que os agentes econômicos possam pautar suas condutas, conforme será visto adiante. Em razão disso, para este trabalho, ainda que sejam mencionados os deveres do "juiz" (de maneira singular), dever-se-á entender o vocábulo "jurisprudência”2 como aquele que exprime o consolidado de decisões de tribunais, no mesmo sentido, que construam um "entendimento pacífico”, de forma a garantir segurança e previsibilidade a esses agentes. ${ }^{3}$

Além disso, em razão do desenrolar das pesquisas que culminaram neste texto, optei por não aprofundar, na medida em que incidentais, as análises dos novos dispositivos do Código Civil à luz de preceitos da teoria econômica. Tampouco objetivei 
realizar análise econômica da reforma legislativa advinda com o novo diploma civil. Todavia, é possível dizer que, por vezes, mostrou-se imperioso o olhar sobre a ciência econômica concomitantemente à análise jurídica realizada, já que não foi possível encontrar no Direito todas as respostas ou fundamentações às proposições surgidas. Exemplo disso: um dos intuitos do texto foi prever o modo de aplicação ou não-aplicação de alguns artigos do Código Civil às relações empresariais por meio de uma interpretação ampla e conjunta, ou seja, delineada pela análise interpretativa jurídica, econômica e social buscando soluções para essas regras (i) nelas próprias, (ii) no ordenamento como um todo, (iii) em diversos conceitos próprios da teoria econômica e (iv) na conduta dos agentes econômicos.

Em razão da ausência de preocupação em nomear a ciência ou área afeita a cada solução buscada no texto, muitas vezes as "linguagens" se confundem e misturam. Na verdade, os parâmetros interpretativos diferenciados mencionados neste texto nada mais são do que a expressão do padrão de racionalidade do agente econômico verificado no mercado. Além disso, o papel da jurisprudência como orientação consolidada ou "pacífica” de que este texto cuidará adiante nada mais é do que o atendimento da necessidade jurídica "e" econômica de segurança e previsibilidade. ${ }^{4}$

Ainda com base nas premissas negativas para delineamento do foco deste trabalho, cuidei da demonstração da ampliação dos poderes do juiz pelo processo civil e do aumento do papel da jurisprudência por via de conseqüência no último tópico deste texto, mas optei por não tratar do papel da prestação jurisdicional, seja por parte do Estado, seja por formas privadas de solução de controvérsias. ${ }^{5}$

Em conclusão, a reformulação das questões primeiramente tomadas para o início do trabalho levou-me ao questionamento que pode ser extraído das linhas gerais do texto, ainda que estas não o proponham diretamente: é possível a convivência do antagonismo entre duas necessidades do Direito Empresarial: (i) a flexibilidade advinda do informalismo e dinamismo do ambiente em que se travam as avenças empresariais e (ii) a segurança protetiva do Direito e a previsibilidade da jogada alheia por meio desta? Deixo ao leitor a tarefa de responder, a partir das conclusões deste texto, se a jurisprudência consolidada atua de maneira a dirimir ou minimizar este conflito.

\section{Princípios, ClÁusulas gerais E CONCEITOS LeGAis indeterminados}

A doutrina denominou de "cláusulas gerais" as disposições genéricas e abstratas trazidas "no corpo" de alguns artigos do novo Código Civil. Interessam a este trabalho as disposições de Direito Obrigacional Empresarial e o estudo dos artigos não será o foco do texto, ainda que alguns deles sirvam de ilustração. Pretendo avaliar os papéis dos poderes dos juízes e da construção jurisprudencial diante dos dispositivos mencionados e, para tanto, importante, de início, diferenciar princípios, cláusulas gerais 
e conceitos legais indeterminados, especialmente quanto à utilização destes nas decisões judiciais.

Em sua obra I principi generali, ${ }^{6}$ Alpa (1993, p. 45) afirma não existir uma definição de "princípios" universalmente aceita e que cada autor dá sua própria definição, distinguindo-os das disposições escritas, dos valores, dos standards, dos conceitos, das cláusulas gerais, das máximas, dos brocardos, "preenchendo-os" como mais lhe aprouverem para poder atingir os objetivos que queiram perseguir, como "caixas vazias".

Fazendo ainda a ressalva de que cada definição esconde um pré-juízo, ou seja, o modo em que o intérprete entende o termo a definir, o seu emprego e o seu contexto ${ }^{7}$ o autor conseguiu enxergar duas concepções de princípios em particular: aquela que entende "o princípio como regra geral que se funda sobre (ou se induz a partir das) regras expressas no ordenamento" e outra que considera princípio "um prius, metajurídico ou extralegislativo", dando a entender que, se os princípios preexistem nas normas, não são mais do que "manifestações sensíveis do princípio" (ALPA, 1993, p. 46). Ambas as definiçõos imputam aos princípios as características de serem expressos em fórmulas genéricas e imprecisas.

Contudo, mais abrangente pareceu uma outra definição, trazida pela moderna teoria de interpretação jurídica: "os princípios embasam as regras e lhes são hierarquicamente superiores, configurando, pois, o sistema”, razão pela qual desempenham papel fundamental na interpretação do direito e dos atos jurídicos; "a exegese há de ser empreendida a partir da consideração dos princípios que conformam o ordenamento. Afinal, as regras são concreções de princípios". 8 _ 9

E, funcionalmente, talvez incorrendo no pré-juízo criticado por Alpa, a noção de "princípio" que mais serve à comparação que se quer demonstrar adiante neste texto é a de Grau (2003, p. 95):

[...] um sistema jurídico ou ordenamento jurídico não será jamais integrado exclusivamente por regras. Nele se compõem também princípios jurídicos ou princípios de Direito. São utilizados pela jurisprudência para fundamentar decisões. Diz-se que tais princípios são descobertos no direito positivo e, aí, passam de princípios descritivos a princípios positivados de inspiração doutrinal. Princípio geral do direito é, assim, princípio ainda não positivado, mas que pode ser formulado ou (re)formulado pela jurisprudência (grifos nossos).

O autor supracitado menciona a jurisprudência, o que corrobora a idéia de Bergel (2001, p. 108) de que "os princípios gerais do direito não têm existência própria competindo ao juiz dar-lhe força e vida, em uma certa representação das relações entre o homem e o poder" (grifos nossos).

Nesse sentido, fez-me notar com mais interesse para este trabalho o início da obra I principi generali, em que Alpa (1993, p. 6/9) ${ }^{10}$ trata especificamente do "uso 
jurisprudencial dos princípios”. Diz o autor que a jurisprudência tende a considerar o princípio como regra geral e abstrata, aplicável a diversos tipos concretos e que se obtém cumprindo sucessivas subsunções de regras particulares específicas e circunscritas a conteúdo mais amplo, reconduzíveis todas ao ápice, ao vértice, justamente o princípio.

Para ele, em cada caso, a jurisprudência oferece exemplos de utilização dos princípios ou de locuções sobre princípios "que aparecem para subtrair o trabalho dos intérpretes a um quadro claro de referências e de conexões lógicas"1 1

Diante de uma perspectiva formalista, Alpa (1993, p. 13/18-23) ainda menciona que, para o uso jurisprudencial dos princípios, estes assumem funções diversas - integrativa, interpretativa, delimitativa e fundante - e que, em um quadro sistemático de usos dessas funções pela jurisprudência, duas modalidades destacam-se: "o uso formal", no qual se ressalta o principio como técnica interpretativa e "o uso 'teleológico", no qual se ressalta o princípio como técnica de manipulação finalística.

Diversos foram os usos dos princípios indicados pelo autor nas duas modalidades citadas. Na primeira, os usos foram: (i) para criação da "regra do caso" (criação da norma aplicada ao caso concreto pelo juiz a partir dos princípios em conexão ao ditame normativo); (ii) como regra geral ou fato normativo preexistente (ao contrário de como resultado da interpretação de um dispositivo); (iii) na orientação do juiz na escolha interpretativa do texto da lei; e (iv) como limite aos poderes interpretativos dos juízes.

Na segunda modalidade destacada, a do uso finalístico, vale destacar o uso de princípios para suprir lacunas legislativas, admitir vantagens entre as partes (ex. Administração Pública em juízo), entre outros menos conexos ao enfoque deste texto.

Assim, diante das diversas concepções sobre a conceituação de princípio e do recorte trazido por Alpa sobre "os usos" destes pelos juízes e, via de conseqüência, pela jurisprudência, vê-se "que os princípios jurídicos, não expressos no direito positivado, fazem parte do ordenamento jurídico com função interpretativa e supletiva da ordem positivada”. ${ }^{12}$

Já as denominadas "cláusulas gerais" 13 foram trazidas pelo Código Civil com a dupla função de: (i) mobilidade, uma vez que atenuam as regras mais rígidas, e (ii) atuar de forma a concretizar o que se encontra previsto nos princípios gerais de direito e nos conceitos indeterminados (MARTINS-COLA, 1992, p. 50). Estas são diferentes dos princípios, "uma vez que estão positivadas", ou seja, são formulações também de caráter genérico e abstrato, mas contidas na lei. Em razão desse caráter genérico e abstrato, as cláusulas gerais devem ser preenchidas pelo juiz autorizado para assim agir em decorrência da formulação legal da própria cláusula geral, que tem natureza de diretriz. ${ }^{14}$

A importância e o papel do juiz e da jurisprudência, que quer tratar este texto, estão diretamente relacionados à tarefa de "preencher de valores"15 as cláusulas gerais. 
Veja que, quando o juiz está diante de um "conceito legal indeterminado", cabe a ele, no momento de subsunção do fato à norma, preencher "os claros" e dizer se a norma atua ou não no caso concreto. Em outras palavras, neste caso, a solução já está preestabelecida na própria norma legal, que enuncia o conceito indeterminado e dá as conseqüências dele advindas, "de forma que ao juiz competirá apenas aplicá-la ao caso, sem exercício de função criadora”. ${ }^{16}$

Assim, apenas como parâmetro negativo de delimitação da noção de cláusulas gerais, vale dizer que estas são diferentes também de "conceito legal indeterminado" pela finalidade e eficácia, já que permitem ao juiz preenchê-las com os "valores designados para aquele caso para que se lhe dê a solução que ao juiz parecer mais correta" (NERY JÚNIOR, 2003, p. 409), ou seja, concretizando os princípios gerais de direito e determinando o conceito abstrato contido na cláusula geral "pela função" que esta deverá exercer no caso concreto.

Neste sentido, segundo Alpa e Bessone (2001, p. 18), ${ }^{17}$ o papel do juiz consiste em dirimir os conflitos aplicando a lei, mas a aplicação pressupõe a interpretação da lei da qual se diz (extrai) o conteúdo criativo, especialmente nas hipóteses em que se devem aplicar "cláusulas gerais", termo criado pela doutrina alemã que indica teor geral, não específico e de conteúdo "especificado” pelos juízes, de vez em quando, segundo o desenvolver dos hábitos e da voz dos cidadãos: em uma palavra, "da consciência social”.

Sendo, então, as cláusulas gerais "normas" - fontes de direitos e deveres - de "ordem pública"1 8 - conforme o art. 2.035 do Código Civil -, estas podem e devem ser aplicadas pelo juiz, inclusive de ofício. O fato de serem consideradas de ordem pública é de extrema importância para o Direito Privado, eis que este tipo de norma tem um peso determinante na ratio decidendi das controvérsias levadas a juízo porque o controle judicial sobre a base do ordenamento jurídico é dirigido a invalidar a relação se esta for com aquela contrastante. ${ }^{19}$

Ora, se as cláusulas gerais "devem" ser aplicadas e as conseqüências desta aplicação - "ao contrário" da subsunção do fato a um mero conceito legal indeterminado - serão estipuladas pelo juiz, então, aqui se verifica “o primeiro apontamento" da importância (i) do papel do juiz (ampliado) e (ii) da jurisprudência majoritária, a qual, ao pacificar um entendimento, pautará as decisões dos agentes econômicos como "regra". Este ponto, o qual será acrescido de outros argumentos, demonstra em verdade o que não se pode negar: que a jurisprudência é, sim, fonte "não formal" 20 do Direito, ao contrário do que afirma parte da doutrina.

Assim, ainda que se aborde, exemplificativamente, o modo de aplicação do conteúdo de cláusulas gerais estabelecidas pelo Código Civil, conforme já mencionado, não se pretende neste trabalho analisar seus conteúdos profundamente, tampouco suas vantagens ou desvantagens, ${ }^{21}$ mas sim determinar o que estas representam para o Direito Empresarial e o papel da jurisprudência, como fator de previsibilidade, diante das referidas inovações legislativas. 


\section{INTERPRETAÇÃO “AUTÊNTICA" DO JUIZ}

Não se pode tentar analisar o papel do juiz e da jurisprudência no contexto da regulação das relações obrigacionais no Direito Comercial, diante da promulgação do Código Civil de 2002, sem antes fazer a ressalva de que "os artigos que abordam a matéria serão tratados como normas". Dessa forma, a inovação que se buscou neste trabalho reside na constatação de que o tratamento jurídico das relações entre as pessoas - físicas e jurídicas - extrapola o texto do Código: aqui não se fala somente do texto legal, mas justamente deste enquanto norma, 22 "após sua interpretação".

Para que se entenda como é possível o Código Civil trazer dispositivos que podem ser aplicados tanto nas "relações civis" entre cidadãos como naquelas empresariais (em que o padrão de conduta do agente envolve profissionalidade e dinamismo), é necessário também que se diga que a norma só existe de maneira completa quando "interpretada".

Assim, só podemos dizer que se trata de "norma” quando esta já passou pelos olhos do intérprete e, para tornar a afirmação mais nítida, cabe destacar a definição de "interpretação" de Grau:

[...] interpretar é, além de compreender, reformular ou reexprimir o objeto da interpretação sob forma nova. A interpretação, assim, consubstancia um processo intelectivo através do qual, partindo de fórmulas lingüísticas contidas nos atos normativos, alcançamos a determinação do conteúdo normativo. ${ }^{23}$

Mas o intérprete não só "produz" a norma (mas também, às vezes, a "reproduz", uma vez que o texto normativo pode não possuir significações diferentes), mas é a moldura da construção da decisão-norma, que terá seu sentido dado pela realidade, ainda que não seja o intérprete o criador da moldura em si. Assim, "a norma encontra-se (parcialmente), em estado de potência, involucrada no enunciado (texto ou disposição); o intérprete a desnuda". ${ }^{24}$

Tendo como pressuposto, então, que a "norma" nasce da interpretação, os juristas como um todo, ou todos aqueles que interpretam o Direito, em alguma medida, produzem normas, até o momento anterior ao da definição da "norma de decisão". Quem produz esta última é o "intérprete autêntico": o juiz revestido de poder para "criar" as normas jurídicas. 25-26

Assim, o ato de vontade ou escolha do órgão estatal aplicador do Direito "dá feição à interpretação autêntica" e, neste sentido, é a única interpretação que efetivamente “cria Direito" - porque a interpretação do advogado não é “vinculante” para o órgão que aplica a norma jurídica.

Desta feita, se "os textos (= as leis) nada dizem, eles dizem o que os intérpretes dizem que eles dizem"27, e se só o juiz pode "criar norma" ao decidir por meio de uma construção interpretativa que vincula as partes submetidas "ao sentido" dado 
àquela por ele, então, vê-se claramente “a função/poder do juiz" de dizer o direito e “a função/poder da jurisprudência pacificada” de tornar o direito criado estável o suficiente para previsibilidade de condutas.

Importante dizer, ainda, que o juiz não pode se furtar de julgar ou "dizer o direito". Esse poder jurisdicional não pode ser afastado, uma vez constitucionalmente previsto 27 e porque "o dever-de-julgar confere completabilidade ao sistema; não é a completude condição do dever-de-julgar [...] a omissão do juiz não se harmoniza, em tese, com o ordenamento jurídico dentro do qual o juiz é juiz" (VILANOVA apud CAMPILONGO, 2002, p. 81). ${ }^{28}$

Assim, "o segundo ponto" que se quer demonstrar neste trabalho passa a ser enxergado:

(i) se as cláusulas gerais são, conforme os dizeres de Nery Junior (2003. p. 408), "normas orientadoras sob forma de diretrizes, dirigidas precipuamente ao juiz, vinculando-o ao mesmo tempo em que lhe dão liberdade para decidir”; e

(ii) se somente o juiz será aquele que dirá quais as conseqüências advindas da aplicação da norma de forma vinculante, "criando o significado desta e preenchendo a cláusula geral”.

Então, os poderes dos quais é investido o juiz (de criação de direito por meio de tomada decisão) foram nitidamente ampliados pela "vagueza" do que se denominou cláusula geral.

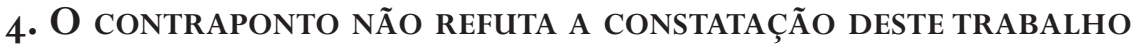

Creio que não se pode pensar em texto de cunho acadêmico elaborado com seriedade se o autor não se debruçar sobre constatações contrárias às suas, sob pena de crer ser a sua a "verdade absoluta" provavelmente inexistente. Muitas vezes, essas "opiniões” contrárias não são expressas no texto, mas aguçam o autor a refutá-las ou acolhê-las e, de qualquer modo, acabam por enriquecer o trabalho.

Muitos foram os contrapontos que encontrei quando passei a acreditar que a jurisprudência é, sim, ainda que de maneira sui generis, fonte do Direito.

Cabe aqui mencionar algumas palavras de Nivarra, Ricciuto e Sconamiglio (2003, p. 14 et seq.) que, a meu ver, como tantas outras, refutam, mas, ao mesmo tempo, não desautorizam o que acabei por "pregar" neste trabalho. Para esses autores, a jurisprudência (ou seja, complexo de decisões pronunciadas pelos juízes) não é fonte do Direito e o juiz tem tão-somente alguns deveres: interpretar uma norma geral e abstrata, quando esta necessitar e, uma vez interpretada, aplicá-la ao caso concreto colocado em face do juízo pelas partes.

Ainda dizem que a Corte di Cassazione, por sua vez colocada no vértice do sistema judiciário italiano, pronunciando suas decisões, portanto, em última instância, 
tem o dever de assegurar a exata observância e uniforme interpretação da lei (conforme o art. 65 dell'ordinamento giudiziario), corrigindo eventuais interpretações que tenham sido equivocadas e cujo conteúdo tenha sido emanado da instância inferior. Assim, para estes, não se trata de atividade criativa de nova regra, mas, sim, de atividade interpretativa e de aplicação de regras já existentes e, mesmo que a atividade interpretativa requeira do juiz uma contribuição criativa (a exemplo de regras que sejam lacunosas ou extremamente genéricas), a eficácia da sua decisão é limitada somente às partes em juízo: a interpretação fornecida pelo juízo não vincula os juízes que serão chamados a julgar casos de conteúdo análogo, mas admitem: "Se o quanto dito até aqui é verdade, é, porém, igualmente verdadeiro que freqüentemente a interpretação dada pelos tribunais a uma disposição de lei possui, de fato, uma eficácia persuasiva, muito mais do que transcurável”, ${ }^{29}$ e partem daí para a conclusão de que, ao buscar o significado de uma disposição, os operadores do Direito - de fato - dão muita atenção ao modo como a regra foi interpretada no passado (especialmente pelas cortes superiores) e esta eficácia persuasiva é tão maior quanto mais consolidado o entendimento e acaba, ao final, por firmar um entendimento que mitiga a própria liberdade da atividade interpretativa - uma vez que os juízes, provavelmente, não adotarão posição diferente daquela já "consolidada”.

O entendimento desses autores é contrário ao que se expõe neste texto, mas a admissão da ressalva acima transcrita é, em verdade, a admissão de um dos mais fortes argumentos utilizados e que embasa a posição aqui "defendida". Dessa maneira, este estudo não demonstra "nadar contra a maré", mas analisar a realidade e provocar a reflexão, tendo por base certas premissas que não são refutadas nem por aqueles que discordam da conclusão construída.

Não se trata de simplesmente propor a adoção do sistema jurídico da common law, e sim de observar a dinâmica do próprio sistema romano-germânico, fugindo da ingenuidade e atentando para a lógica interpretativa que se enxerga na prática do Direito nos países que adotam esse último sistema. Ora, dessa maneira, tanto não se pode dizer que a jurisprudência é "fonte direta, formal e vinculante" do Direito no sistema romano-germânico (em razão das normas de interpretação que dizem o contrário), como não se deve ignorar, assim como os autores que ora cito exemplificativamente, que a orientação jurisprudencial “consolidada” ronda a razão e permeia as decisões judiciais, sendo "fonte informal direta" do Direito.

Para ilustrar com um exemplo brasileiro, seguem as palavras do Ministro Afrânio Antônio da Costa, em seu voto (p. 482) no Recurso Extraordinário 15.906/MG, cujo relator era Álvaro Ribeiro da Costa, julgado pela 1. ${ }^{a}$ Turma do STF em 08.05.1950: “[...] Ponderei sobre a questão, porque, como é dever de todo juiz, disciplinar-me-ei pela jurisprudência do Egrégio Supremo Tribunal Federal. E com o maior acatamento fui procurar a razão de ser para o meu modesto voto, à margem 
da jurisprudência do Egrégio Supremo Tribunal Federal, convencendo-me, data venia que o argumento é ponderável [...]”.

Em conseqüência, essa relativa previsibilidade acarreta o direcionamento da conduta dos agentes econômicos. Nesta medida, a conclusão sobre jurisprudência ser fonte sui generis do Direito, ainda que informal, ${ }^{30}$ coube ser trazida a este texto, neste tópico, o que complementa outras conclusões adiante.

\section{Cláusulas gerais no Direito Comercial, JURISPRUDÊNCIA, NORMA E REALIDADE}

É bem verdade que, ao observar, por exemplo, a "arte”, nota-se que o homem é um ser ilimitadamente "criativo". Contudo, é fato que tanto o texto puro das leis e avenças $^{31}$ - porque elaboradas pelos homens - quanto os seus intérpretes sofrem de limitação de completude em razão do que a teoria socioeconômica denomina de "limitação de racionalidade". Segundo Leonardo L. Ribeiro, o conceito trata do "reconhecimento de que o ser humano é limitado em sua habilidade de formular e solucionar problemas", além de apontar a sujeição dos seres humanos à assimetria de informação nos seus relacionamentos, às perspectivas subjetivas na forma com que cada indivíduo observa e assimila o mundo que o cerca e à própria limitação da sua capacidade cognitiva, situação agravada "pela existência de custos" para procurar, obter, armazenar, processar e utilizar informações. ${ }^{32}$ Também, em razão dessa característica do próprio ser humano, coerente foi a escolha do legislador brasileiro em inserir no Código Civil as antes conceituadas "cláusulas gerais". Contudo, essa inserção traz questionamentos de ordem teórica e prática quanto à aplicação dessas normas aos negócios jurídicos celebrados no ambiente empresarial, seja porque basilares para o bom andamento da economia, seja porque celebrados em ambiente mais dinâmico, entre outros motivos.

Assim, além dos poderes do juiz, ditos ampliados pela inserção de cláusulas gerais no Código Civil e das últimas reformas processuais (adiante mencionadas), importante analisarmos também o papel da jurisprudência diante da inovação legislativa.

Para aplicação do regramento positivado às obrigações advindas de relações empresariais, as regras precisam ser interpretadas, conjugando a observância (i) da realidade factual; (ii) dos $\operatorname{usos}^{33}$ (no caso do juiz, tanto para a ratio decidendi quanto como propriamente um elemento de convencimento); e (iii) da jurisprudência "pacificada”.

Ao depreender outras "funções" da mencionada "jurisprudência pacificada", Cruz e Tucci (2003), citando Giovani Orrù, sobre a eficácia dos precedentes na Itália e Alemanha, traz os seguintes exemplos:

1) a jurisprudência consolidada garante a certeza e a previsibilidade do Direito;

2) a jurisprudência consolidada assegura a igualdade dos cidadãos perante a distribuição da justiça; 
3) a jurisprudência consolidada evidencia submissão moral de respeito à sabedoria acumulada pela experiência; e

4) a jurisprudência constrói uma presunção (relativa) em prol da justiça do precedente, até porque, sem um razoável grau de confiança na anterior elaboração judicial, faltaria um dos fundamentos mais relevantes da evolução do Direito.

Portanto, a jurisprudência pacificada, além de exercer função de pauta para interpretação das regras, garante também a elas a "estabilidade necessária", na medida em que a manutenção de seu entendimento "estável” se dá de acordo com as necessidades socioeconômicas surgidas e expostas pelas demandas apresentadas perante o Poder Judiciário. Em outras palavras, a estabilidade garantida à interpretação da regra pela jurisprudência pacificada só é alterada quando a sociedade ou o mercado ou um segmento de mercado (dependendo do agente) modifica-se de forma a gerar demandas sociais ou econômicas ou políticas de tamanha relevância ${ }^{34}$ que, pelo balanço de valores e princípios, essas demandas sobreponham-se à estabilidade da interpretação normativa consolidada. Dessa maneira, a consolidação de entendimento jurisprudencial garante, dentro dos seus limites, a normatização das obrigações advindas de relações empresariais pela completude da regra interpretada relativamente estável.

Ao contrário do que prega parte da doutrina, ${ }^{35}$ no sentido de que o mercado e as relações empresariais como um todo se auto-regulam e buscam plena liberdade para criação diante do dinamismo dessas relações, vê-se que a normatização "não" é repudiada pelo mercado. ${ }^{36}$

Aliás, até mesmo a eventual "relativização" do princípio do pacta sunt servanda por alguns dispositivos do Código Civil é muitas vezes, de fato, excelente para o bom funcionamento do "mercado". ${ }^{37}$ O princípio do pacta sunt servanda é o que traz confiança ao sistema, mas é prejudicial se cumprido em detrimento da observância de princípios e regras de lealdade contratual. Assim, pode ser vista a "excessiva onerosidade" como instituto relativizador do princípio citado, mas que exerce função de “azeitamento" das relações - ou até de presunção de boa conduta ou conduta justa dos agentes, o que, conforme já dito anteriormente, é favorável ao mercado.

O texto legal é mero ponto de partida para criação da norma (que só tem sentido concreto quando interpretada) no momento de sua aplicação ao caso. Nesse sentido, importante lembrar que também é requisito necessário para criação da norma de Direito Empresarial o olhar sobre a realidade. Faz parte dessa realidade a situação factual de aplicação da regra, emoldurada pela praxe do empresário e, principalmente, pelo mercado.

Ainda que o precedente judicial deva ser observado, diante da "presunção (relativa) em prol da justiça do precedente” (CRUZ ETUCCI, 2003), é certo, porém, que cada situação concreta deve ser analisada como única, uma vez que apresenta peculiaridades, e sempre dentro do contexto em que se apresenta. 
Grau, em seu discurso de agradecimento proferido na solenidade de entrega da medalha Teixeira de Freitas, menciona que este jurista buscava fazer a ciência do Direito presa a rigores metodológicos, mas sem afastá-la do "mundo da vida" e cita excerto que ora cabe transcrever:

Examinar as leis em seus próprios textos sem influência de alheias opiniões, comparar atentamente as leis novas com as antigas, medir com precisão o alcance e conseqüências de umas e outras, eis que o laborioso processo, que empregado temos para conhecer a substância viva da Legislação. ${ }^{38}$

E comenta: "Essa substância viva é composta pela realidade - em rigor, é parcela da própria realidade - à luz da qual os enunciados dos textos assumem diversos conteúdos normativos"39 (grifos nossos). Dessa forma, ainda que a noção de mercado como locus de atividade econômica suponha a livre competição - conjunto de operações econômicas e modelo de trocas; conjunto de contratos, convenções e transações relativas a bens ou operações realizadas no lugar $/$ mercado $^{40}-$, a regulação de suas operações e das condutas de seus agentes é necessária, eis que é também "instituição jurídica, constituída pelo direito posto pelo Estado, e deste se reclama, a um tempo só, que garanta a liberdade econômica e, concomitantemente, opere a sua regulamentação [= regulação]. Sendo atividade, as regras de mercado consubstanciam o seu substrato".

Diante desta consideração, posso dizer que a regulação do revogado Código Comercial e do atual Código Civil, então, cumpriu e cumpre, respectivamente, função estatal devida ao mercado para a boa fluência das relações econômicas no País.

Em conclusão, levando-se em conta a afirmação de que o texto normativo precisa ser interpretado, em especial se elaborado com intuito de completude diante da aplicação ao caso concreto, e que só a jurisprudência pode garantir a sistematização do entendimento, a partir do seu olhar sob o caso concreto e o ambiente em que este se desenrola, não se pode falar em normatização desejada pelo mercado que não seja aquela que já tenha "passado pelo crivo" da autoridade judicial que trará a ela a completude necessária. Daí a importância da jurisprudência nos casos em que se requer a aplicação de novos dispositivos do Código Civil aos negócios jurídicos empresariais.

Um advogado, como operador do Direito, é intérprete solitário diante da norma e contará não só com suas limitações pessoais, como também com a quase inafastável inclinação a abstrair da norma a interpretação que mais lhe favoreça. Já a jurisprudência é formada de decisões que são o fruto da prestação de um dever (dever de prestação jurisdicional), com suas fundamentações atreladas à imparcialidade e à necessidade de observar cada caso concreto singularmente, mas "dentro" de seu contexto (ambiente, momento, grau de informação das partes etc.). Tais características 
legitimam a jurisprudência como fonte de complementação do sentido da norma com relativos efeitos erga omnes, eis que induzem os atos dos sujeitos de direitos.

Tendo em vista que tão maior é a confiança na posição jurisprudencial quanto maior seja o lapso temporal em que as decisões estejam sendo preferidas em um sentido ou outro, estar-se-ia diante de um problema pelo fato de o Código Civil emanar regras sobre as quais os tribunais ainda não tenham se pronunciado.

Contudo, os novos dispositivos do Código Civil não significam novos fatos, nova prática e, muitas vezes, nem sequer novo Direito. Os negócios continuarão a celebrar-se com suas racionalidades próprias; os conflitos continuarão a existir, porém a mensuração do risco na tomada de algumas decisões poderá ser reavaliada diante de alguns preceitos.

Para verificar se a mensuração do risco deverá ou não ser reavaliada, o empresário olhará a norma e, para enxergar qual será seu mais provável entendimento diante do caso em que se insere, olhará "para trás”. Nesse olhar, verá, ao menos: qual a racionalidade que movia os juízes na aplicação de outras normas; que os juízes necessariamente se debruçavam sobre a realidade e sobre os escritos doutrinários e que tinham suas "amarras" nos princípios constitucionais e naqueles de Direito Empresarial.

Para ilustrar o exposto acima, com intuito de tornar algumas assertivas mais claras, exemplifico adiante algumas previsões interpretativas à luz da doutrina e da jurisprudência atuais e do passado.

\section{Inserção de normas de Direito Comercial no Código Civil: BREVES CONSIDERAÇÕES SOBRE A EXPERIÊNCIA ITALIANA}

Antes de passar pontualmente às ilustrações, cumpre realizar breves considerações sobre a inserção de normas de Direito Comercial no Código Civil por meio de diploma unificado. Neste sentido, cabe ser feito um breve paralelo com a experiência italiana, clara inspiradora da elaboração do Código pátrio, para que depois possa adentrar, de maneira contextualizada, na exemplificação de regras inseridas no Código Civil brasileiro sob a forma de cláusulas gerais e que serão aplicadas tanto às relações de Direito Civil como às de Direito Comercial. Isto porque, como o Código brasileiro, o Codice Civile italiano recorreu bastante à utilização de cláusulas gerais para o Direito Privado, a exemplo de termos como "giusto motivo", "interessi del creditori" dos artigos 1.173, 1.414, "termine congruo" do artigo 1.379, "termine congruo" do artigo 24, entre outros.

Passaram também os italianos por uma codificação una de Direito Privado, em 1942, a qual compreendeu as disciplinas das relações entre particulares, que compõem dois grandes "ramos": o primeiro é o Direito "Civil" (extraído do termo civis, que significa cidadão), que trata de todas as relações privadas com exceção daquelas 
de que cuida o segundo, Direito Comercial, que trata das relações advindas de operações econômicas atinentes ao comércio e à indústria e realizadas com profissionalidade, com exceção daquelas de trabalho.

As razões da unificação das obrigações em um único diploma na Itália foram múltiplas, mas, sobretudo, políticas, eis que a ditadura fascista totalitarista não concebia a possibilidade de duas diferentes categorias de tratamento entre particulares (entre comerciantes ou entre comerciantes e particulares), uma vez que cada relação deveria ser "reconduzida" à mesma fonte - o Estado - e "harmonicamente coordenada com as outras, também para sublinhar que a sociedade, dividida em classes, não conhecia divisões no âmbito do Direito", e que todos "colaboravam com a edificação da sociedade (fascista, corporativa, unitária)”. 41

A dupla codificação - derrogada - era justificada pela necessidade de manter uma disciplina particular própria para tutelar as relações travadas no comércio de maneira mais simples e freqüentes, de acordo com a praxe comercial, além de ser necessária uma regulação "a-nazionale" e o mais geral possível para todos os mercados. Todavia, diante do fato da especialidade do Direito Comercial, as normas elaboradas para o diploma legal italiano de 1942 foram tão influenciadas pelo antigo e revogado Código de Comércio que alguns dizem ter havido, à época, uma "comercialização" do Direito Privado.

Em razão de um dos ideais fascistas, ${ }^{42}$ então, a Itália realizou a unificação do Direito Privado. No Brasil, outras razões a embasaram, mas essas de ideais menos contundentes, dos elaboradores do projeto e que, talvez por isso, não se possam dizer da Nação. ${ }^{43}$

"Oggi la distinzione è rimasta in ambito accademico e scientifico", disseram Guido Alpa e Mario Bessone sobre a diferenciação ${ }^{44}$ entre o Direito Civil e o Comercial, e a doutrina é observada nas decisões dos juízes. Os dois "Direitos" extraídos do Codice Civile foram "assentados" em suas disciplinas pela doutrina e jurisprudência e, creio, assim deverá acontecer no Brasil.

Cabe destacar que as vozes são muitas no mesmo sentido. Tulio Ascarelli destaca que o Direito Comercial é ramo autônomo do Direito, regido por "princípios peculiares"; o elemento de distinção é a "peculiaridade de seus princípios jurídicos”. E ensina:

A explicação da autonomia do direito comercial não está apenas em peculiaridades técnicas necessariamente inerentes à matéria por ele regulada, mas na peculiaridade dos seus princípios jurídicos, acolhidos de início em um âmbito limitado [...], sucessivamente em um âmbito mais vasto. ${ }^{44}$

Além da peculiaridade principiológica, cabe destacar outra importante diferenciação, uma vez que, conforme Goldschmidt, o que é uma qualidade no Direito Civil - a exemplo da formalidade - pode ser um defeito no Direito Comercial. ${ }^{45}$ 
Assim, não serão deixados de lado todos os escritos da tradição doutrinária pátria, tampouco será desprezada a evolução construída pela jurisprudência, em especial em algumas disciplinas de Direito Comercial, uma vez que os "institutos" próprios deste Direito particular existem na prática do empresariado da maneira que são necessários, do modo como nasceram.

Tendo em vista todo o exposto, conforme dito no tópico anterior, passo a "exemplificar" 46 como algumas chamadas "cláusulas gerais", que tanto aumentaram o poder dos juízes e o papel da jurisprudência, quando aplicadas ao Direito Comercial pelos tribunais, não gerarão risco excepcional aos agentes empresários. As relações destes mantêm-se "protegidas" pelos princípios próprios de Direito Empresarial, em especial pelo padrão de mercado que deve orientá-los.

\section{I ILUSTRAÇÃo}

\section{I. I ABUSO DE DIREITO}

O primeiro exemplo é a cláusula geral de “abuso de direito" expressa no artigo 187 do Código Civil de 2002, que apresenta, para sua configuração, a afronta ao "fim econômico". Nesse artigo, a expressão "fim econômico", "no Direito Empresarial", equivale à "função econômica", ou seja, a "razão" pela qual as partes celebraram o contrato, não confundida com o mero intuito de obter lucro. Em palavras similares, disse Chiovenda (1933, p. 188) que ninguém contrata pela mera intenção de trocar declarações de vontade, ou seja, as partes sempre apresentam uma razão ou estímulo para contratar, uma "causa". 47

Contudo, não podem ser generalizados os termos da afirmação supra, sob pena de perder o sentido da aplicação das cláusulas gerais. Assim, o juiz que buscar dirimir conflito em que se perquira se houve ou não afronta ao limite estabelecido no artigo 187 não pode afirmar que a função econômica do determinado contrato era "obter lucro", mas deve buscar, na(s) vantagem(ns) obtida(s) de cada contratante e na medida dos riscos por eles assumidos, os "porquês" da contratação e o modo em que esta se deu.

Dessa forma, o parâmetro para verificar o abuso é, então, o atentado à mencionada "função econômica", a ser auferida pelo juiz não pela estrita interpretação do contrato em si, mas pela lógica que envolveu a formação daquele, dentro dos parâmetros de mercado em que se insere. A doutrina italiana denomina esta técnica de análise como o instituto da "presupposizione", 48 por meio do qual o juiz buscará determinar qual era o "interesse comum dos contraentes" no momento da contratação. Em razão dessa teoria, a tipicidade contratual é benéfica a esta verificação, uma vez que explicita padrões de condutas dos contratantes em um ou outro mercado, de acordo com um ou outro tipo de contrato que seja celebrado. Ao escolher um tipo contratual, observa-se a sua função econômica, lógica das partes de terceiros e o funcionamento (almejado) deste no mercado. 
Somada a análise do “interesse comum dos contraentes” e da lógica da boa-fé, em busca das pressuposições, será necessário que o magistrado também se debruce sobre a razão que norteou a conduta questionada em juízo como abusiva, que pode representar uma vantagem para aquele agente - e somente para ele - ou pode ser considerada uma prática para o melhor funcionamento do negócio que, ao final, gerará vantagens a todos. ${ }^{49}$ Se a conduta funcionará em prol do "negócio" como um todo e não para o interesse singular de uma parte, não se vislumbra a possibilidade de que esta seja tida como abusiva porque não contraria a função do contrato, mas só o interesse ou até o "gosto" do outro contratante. Infelizmente ou felizmente, o Direito Empresarial não socorre aqueles que querem ver supridos seus gostos ou caprichos, a não ser que estes estejam inseridos nos padrões de conduta esperada ${ }^{51}$ do agente econômico no seu mercado específico (em bom funcionamento) e de acordo com a função econômica do contrato.

\section{I. 2 BOA-FÉ OBJETIVA}

Ainda que a boa-fé objetiva não seja novidade ${ }^{50}$ para interpretação dos contratos no Direito Empresarial, tampouco como pauta para execução destes ou para delimitação e até criação de obrigações neste ramo do Direito, ${ }^{51}$ cabe mencioná-la entre os exemplos ora trazidos, eis que remanesce aplicável às relações comerciais e é mencionada (direta ou indiretamente) pelo Código Civil brasileiro nos artigos 113,187 e 422.52

O padrão de boa-fé objetiva, nas suas duas funções principais no Direito Comercial - ou seja, servir de pauta de interpretação e de fonte de obrigações -, é extraído do que é denominado "comum" ou "praxe" (padrão para garantir a calculabilidade da afronta ou não afronta) no bom funcionamento do mercado. A boa-fé é "calculada" de acordo com o que se pode presumir da vontade das partes no mercado em que esses agentes econômicos atuam.

Mas não só. Posso, a partir disso, afirmar que o padrão da boa-fé objetiva no Direito Comercial é extraído da necessidade de segurança, previsibilidade e confiança para as condutas dos agentes; dos usos e costumes; da intenção comum das partes; da praxe e contexto de mercado; e do azeitamento do fluxo das relações de mercado atingidas pela preservação obtida com a regulação. ${ }^{53}$ Esses não são, contudo, padrões para calculabilidade da boa-fé nas relações civis e esta afirmação é resguardada pela construção jurisprudencial. Por diversas vezes, a posição da jurisprudência já atestou a importância do mercado, bem como o diferenciado padrão de conduta do comerciante, que age com profissionalidade. Para não me furtar do dever de ilustrar e embasar a assertiva, aproveito trecho extraído de acórdão proferido pelo Tribunal de Justiça paulista em 1913, mencionado e transcrito pela Professora Paula A. Forgioni ${ }^{54}$, conforme a seguir, em merecido destaque: 
Em 1913, o Tribunal de Justiça do Estado de São Paulo tratou da seguinte questão: um comerciante vendeu sua loja a outro, acordando que não se restabeleceria na Rua da Consolação. No entanto, instalou-se em rua próxima. Haveria má-fé? Entendeu o Tribunal que não, porque isso não havia sido acordado. Aliás, o vendedor poderia ter limitado a zona de proibição do restabelecimento; não o fez à época do negócio e não o poderia fazer posteriormente.

Em nota de rodapé, a autora transcreveu trecho do acórdão:

Vale transcrever, aqui, esse julgado: "O Apelado explorava certo ramo de negócio á rua da Consolação, nesta capital. O Apelante, vendo-lhe a prosperidade, propoz-lhe a comprar-lhe o estabelecimento se ele quizesse tomar o compromisso de não abrir naquela rua negocio identico. A proposta foi bem acolhida, a transação foi ultimada e o compromisso foi assumido. O homem não tardou, porém, a mostrar ao seu successor que mereceria a prosperidade comercial que o favoneava. Era, de facto, da cabeça aos pés, um negociante esperto. Foi a uma rua próxima á da Consolação e abriu outro negocio... O comprador do negocio antigo pulou de raiva. Aquilo era mais do que uma deslealdade: era uma violação positiva ao compromisso assumido. - Engano, meu amigo, puro engano, volveu o homenzinho com placidez. Nem uma cousa nem outra: nem deslealdade nem violação de compromisso... A que foi que eu me comprometi? Não fio a isto apenas: a não abrir na rua da Consolação negocio identico ao que lhe vendi? [...] - Boa duvida! Que importa que não abrisse na rua da Consolação se abriu nas proximidades dessa rua? O transtorno que me causa é sempre o mesmo. - Perdão. É possivel que assim seja. Mas eu nada tenho com isso. A minha obrigação é apenas a de respeitar o compromisso, e o compromisso é muito claro: 'rua da Consolação, negocio do mesmo gênero'. Não diz palavra sobre proximidades daquela rua. [...] Foram a juízo. O Juiz, tanto o de primeira instancia como o Tribunal, concordou com o negociante e repeliu a pretensão do outro. O compromisso só se referia á Rua da Consolação. Nada dizia quanto ás suas proximidades. A abertura de novo negocio, em outra rua, embora proxima daquela, não o violou. Observaram, ainda, os srs. Ministros: '- Porque, no contrato, esse cidadão não falou tambem nas proximidades da rua da Consolação? Podia até marcar a zona dentro da qual ao outro não seria permitido comerciar... Não o fez! Quer fazer agora?' ACÓRDÃO: Accordam em Tribunal de Justiça [...] confirmar, como confirmam, a sentença appellada [...]. Julgado em 13 de dezembro de 1913, por Xavier de Toledo, A. França, Meirelles Reis e Rodrigues Sette” (as aspas que iniciam e findam as falas dos "personagens" foram por nós 
colocadas). Os embargos, posteriormente opostos, foram rejeitados e o acórdão confirmado.

Após, a autora continua: ${ }^{55}$

Ora, percebemos que, neste anedótico julgado, a “esperteza” própria do bom comerciante foi aplaudida em detrimento da outra parte, que não havia se comportado como um mercador diligente. A mesma solução poderia ser dada se se tratasse de um contrato celebrado entre não comerciantes? O mesmo padrão de boa-fé deveria ser considerado? Por certo que não. É isso que precisa restar claro, neste início de vigência do Código Civil: a boa-fé que rege as relações mercantis parte de uma realidade diversa e desempenha uma função um tanto diferente daquelas que cercam a maioria dos negócios celebrados entre não comerciantes.

Cumpre ainda anotar a consideração do quão importante é que se tenha em mente a tradição jurisprudencial brasileira quanto aos padrões de condutas dos agentes nas relações de Direito Comercial, sob pena de incorrer, por exemplo, em equivocadas interpretações protecionistas próprias da lógica do Direito do Consumidor, tão difundida e utilizada nos tribunais brasileiros. ${ }^{56}$

Por fim, concluo pela possibilidade de aplicação dos novos artigos do Código Civil que trazem a cláusula geral de boa-fé, exercendo funções plurais, de maneira distinta ao se tratar de relações empresariais, em conformidade com seus padrões, a doutrina e a jurisprudência já consolidada.

6. I. 3. LESÃO

O terceiro exemplo é o instituto da "lesão", expresso como cláusula geral no artigo $157^{57}$ do Código Civil de 2002. Este dispositivo prevê que será configurada "lesão" quando uma pessoa, "sob premente necessidade, ou por inexperiência”, obrigar-se à prestação manifestamente desproporcional ao valor da prestação oposta, salvo se for oferecido suplemento suficiente ou se a parte favorecida concordar com a redução do proveito, sob pena de ser decretada a anulação do negócio.

Primeiramente, observo que nem sempre as partes contratadas terão igualdade de prestações, ao contrário, na maioria das vezes, isso não acontece. Pereira (2001, p. 205) menciona que não se pode pretender a igualdade absoluta das prestações e que, diante disso, o Direito:

[...] tem de observar a repressão da injustiça no plano ideal, disciplinando as condutas em certos setores de atividades em que, por força das circunstâncias 
ou das desigualdades das partes, o contrato reflita descompasso atentatório da comutatividade. ${ }^{58}$

Em razão da impossibilidade de exata igualdade de contraprestações e pelo fato de o contratante, no âmbito empresarial, escolher quais os riscos que pode ou não assumir é que, muitas vezes, advogados que realizam intermediações de contrato empresariais são "taxados" sob a "pecha” daquele que dificulta a celebração do negócio. Na ânsia de minimizar todos os riscos para o seu cliente, o advogado "litiga" na celebração do contrato, o que pode ser inclusive atentatório ao interesse maior daquele que está sendo "protegido": a celebração do negócio.

Bem como resta frustrado o advogado que tenta impor todas as limitações e proteções ao seu cliente em cláusulas contratuais, não poderá supri-las o magistrado por meio da aplicação inapropriada do artigo 157 do Código Civil. É claro que a força econômica, entre outras circunstâncias, como o grau de acesso à informação (ou simples assimetria), acaba por moldar parte da negociação, mas as cláusulas que regerão aquele negócio expresso em contrato são fruto da assunção de risco ponderada por cada parte.

Além disso, menciona Pereira (2001, p. 205) que somente no plano ideal poder-se-ia vislumbrar a lesão a partir do desequilíbrio tão evidente entre as partes que a desproporção das prestações bastasse para revelar exploração. Em razão disso, o próprio artigo que a define traz a necessidade de sua configuração por dois elementos cumulativos:

a) a desproporcionalidade das prestações e b) o dolo de aproveitamento caracterizado pelo abuso daquele que está "sob premente necessidade" ou que seja inexperiente.

Quanto à necessidade contratual, Pereira (2001, p. 1999) ensina que não se confunde a "necessidade" com a "pobreza", mas, sim, a circunstância de ter o declarante de realizar aquele negócio "independente do seu estado de fortuna", "para a satisfação de necessidade e que em razão da necessidade o contraente seja compelido a contratar em situações iníquas", e ilustra: "exemplo frisante que se apresenta é o de um pai que tem de tratar um filho gravemente doente ou gravemente ferido, e se vê na contingência de pagar um preço absurdo por aquilo que em circunstâncias normais lhe custaria muitíssimo menos". O autor traz ainda exemplo que entendo em desconformidade com seus próprios ensinamentos, mas que cabe a mim, no dever de expor, e não de convencer, transcrever: "alguém em estado de insolvência, que tem de vender suas coisas, para realizar prontamente recursos em dinheiro".

Para ater-me ao foco exemplificativo da aplicação do instituto no ambiente empresarial, cabe dizer que, tradicionalmente, o instituto da lesão, como desenhado para o Direito Civil, é excluído dos contratos empresariais. Diz-se que Visconde de Cayru já referia que tal instituto só poderia ser alegado "nas vendas a retalho com o povo". 
Contudo, o referido jurista, em sua obra Principios de direito mercantil e Leis da Marinha (LISBOA, 1874, p. 470-471), ao tratar dos requisitos essenciais para validade dos contratos mercantis - que consistiam em nove -, entre eles, ${ }^{59}$ mencionou: “que não haja lesão enorme, e menos enormissima”. Sobre a falta deste requisito para validade do contrato, o mestre admite que "se rescinde o contracto em que interveio lesão contra a natural equidade e conhecido valor da cousa na geral estimação do lugar e tempo em que se celebrou o mesmo contracto", e faz a importante ressalva: "porém entre commerciantes, e em effeitos mercantis, a não ter havido arte e engano, he raro, pouco honroso e inadmissível allegar-se lesão, a não ter havido arte e engano da parte contraria” ( grifos nossos). E continua:

Todo contracto em que há igualdade e rectidão, isto he, que esta em grao, ou circumstancias de poder dar a ambas as partes igual lucro ou damno, correndo ambos a sorte de perder ou ganhar, deve-se considerar racionável, proporcionado e justo [...] E nada abona tanto, e dá credito a qualquer negociante e Praça, que a lealdade, inviolabilidade e pontualidade ou religioso cumprimento da palavra, contracto e fé dada [...] são os pactos licitos o mais sagrado e universal vinculo da Sociedade Civil. Vender, e arrepender he o aphorismo pratico em transacções do Commercio (grifos nossos).

Tais ensinamentos encontravam-se em consonância com o título VIII do Código Comercial de 1850, ao tratar da compra e venda mercantil, que trazia o seguinte artigo: "Art. 220. A rescisão por lesão não tem lugar nas compras e vendas celebradas entre pessoas todas comerciantes; salvo provando-se erro, fraude ou simulação”.

Ainda hoje, não faz sentido que o dispositivo, tal como apresentado pelo Código Civil vigente e ilustrado por Caio Mário da Silva Pereira, seja aplicado às relações empresariais, uma vez que, muitas vezes, o agente celebra contratos em que aufere menos vantagens do que o padrão de mercado para "não perder o negócio", diminuindo sua vantagem propositalmente, mas por meio de uma jogada desejada. Outras vezes o próprio segmento de mercado ou a grandeza de um contratante impõe ao outro uma desvantagem contratual e este não deixa de celebrar o contrato em razão disso, já que sabe que a prática o impede de impor outras condições. ${ }^{60}$

Ademais, o empresário é experiente por definição (elemento da profissionalidade o define) e o que lhe impulsiona a contratar é a análise das vantagens auferidas dentro do cálculo organizado de risco, e não a equivalência estrita das prestações de um contrato ou outro.

O "dolo de aproveitamento" caracterizado pelo abuso da inexperiência ou da premente necessidade da outra parte não tem razão de ser diante do fato de o empresário ser experiente por profissão e pelo motivo de, muitas vezes, contratar conscientemente uma situação de desvantagem, uma vez que realmente está em 
“premente necessidade”, ou seja, “precisa 'fechar negócio””, mas que assim o faz com o risco do negócio calculado.

Não enxergo a possibilidade de haver dúvida de que não será considerada em situação de "premente necessidade", para configuração da lesão, a empresa que apresente dificuldades econômico-financeiras advindas de imprevisibilidades danosas de conjuntura macroeconômica ou até de má condução dos negócios por parte do administrador e que celebre negócio de alto risco ou alto custo, voluntariamente, na busca da implementação de uma estratégia para viabilidade da continuação da atividade. Da mesma maneira que ninguém contesta, até porque a racionalidade é óbvia, o fato de o preço do crédito, quando concedido, para empresas em situação econômica deficitária ser maior do que aquele liberado para investimento em novos projetos de empresas plenamente saudáveis.

No ambiente do Direito Empresarial, o agente experiente que calcula mal sua jogada provavelmente será penalizado pelo mercado, que o exclui.

É certo, porém, que, em especial no Brasil, em razão da falta de preparo e/ou instrução de pequenos negociantes para o exercício de suas atividades, nem todo empresário é "experiente”. A questão, então, que pode vir a se colocar é um tanto "regionalista" e pode parecer apologia ao protecionismo da escala econômica dos pequenos empresários, mas não é.

Ao tratar dos desafios para entrar em um mercado de trabalho em que a concorrência para o primeiro emprego é bem maior do que aquela enfrentada para ingressar na faculdade, as jornalistas Weinberg e Brasil (2003), em artigo constante da revista Veja, de 17.12.2003, afirmam que boa parte das empresas daqueles que "trabalham por conta própria" fecha as portas por falta de capital, de clientes, pelo excesso de carga tributária, por culpa de maus pagadores, por não conseguir acompanhar a forte concorrência e por "descuidos comportamentais", os quais "estão entre as principais razões para o fechamento de microempresas". Segundo as autoras, meio milhão de empresas são "abertas" todos os anos e, de acordo com os dados do Serviço Brasileiro de Apoio às Micro e Pequenas Empresas (Sebrae), cerca de metade delas quebra antes de chegar ao segundo ano de vida e somente $30 \%$ daquelas "ultrapassam a marca dos cinco anos". Esta realidade é ainda mais infeliz se traçarmos um paralelo com dois fatos: (i) os altos índices de desemprego no Brasil, muitas vezes, "arrastam” os cidadãos para a tentativa de colocar-se no mercado por conta própria e (ii) muitos profissionais preferem lançar-se no empreendedorismo - em que a renda mensal pode variar entre $25 \%$ e $50 \%$ de um mês para outro - do que procurar por um emprego e galgar uma remuneração "estável”. 61

Não se trata de inserir neste ponto da discussão a importância econômica e social das pequenas empresas, ${ }^{62}$ que participam em grande escala da economia e representam instrumentos hábeis nas mãos do empreendedorismo, tampouco analisar o tratamento 
destas na regulação de mercado e pelo ordenamento jurídico como um todo, ${ }^{63}$ diferenciando-as das grandes estruturas. ${ }^{64}$

Pretendo, porém, formular a seguinte questão: no contexto social brasileiro, o conceito de empresário trazido pelo artigo 966 do Código Civil como aquele que "exerce profissionalmente atividade econômica organizada para a produção ou a circulação de bens ou serviços” e que pressupõe a experiência deste em razão do elemento da profissionalidade pode ser flexibilizado pela realidade social, de forma a dar margem à quebra da racionalidade tradicional de não-aplicação do instituto da lesão aos negócios empresariais?

Creio que a resposta seja negativa.

A inexperiência do pequeno empresário brasileiro que busca o exercício da atividade empresarial como fuga do desemprego não legitima sua salvaguarda contra as forças do mercado. Contudo, essa mesma inexperiência talvez o leve a contratar mal em certas situações em virtude de não ter consciência do significado do ato ou das conseqüências que este possa acarretar. Todavia, a anulabilidade dos atos praticados nesta situação é protegida pelo Código Civil, que, em seu artigo 138, prevê: "São anuláveis os negócios jurídicos, quando as declarações de vontade emanarem de erro $^{65}$ substancial que poderia ser percebido por pessoa de diligência normal em face das circunstâncias do negócio”. Não se trata de dizer que o pequeno empresário despreparado não seja pessoa de diligência normal, e sim de afirmar que este restará protegido quanto ao erro como vício de sua própria vontade quando "traduz-se numa representação inexacta ou na ignorância de uma qualquer circunstância de facto ou de direito que foi determinante na decisão de efectuar o negócio”. ${ }^{66}$ Ainda menciono a possibilidade de anulação do negócio jurídico celebrado em função de omissão dolosa de fatos por parte de um dos contratantes, que leve aquele menos informado a contratar. ${ }^{67}$

Sendo da essência da atividade empresarial o cálculo de risco e o custo da contratação, não há como vislumbrar a possibilidade de aplicação da cláusula geral constante do artigo 157 do Código Civil para situações ocorridas no âmbito das relações empresariais. Mesmo porque tal aplicação causaria danos aos próprios agentes econômicos, em teoria "tutelados" pela disciplina, uma vez que impossibilitaria transações em fase de má situação econômica temporária da empresa ou aumentaria sobremaneira o custo da contratação, inviabilizando-a.

\section{6. i.4 Denúncia contratual}

Optou-se por inserir o artigo 473 do Código Civil, que trata da suspensão da denúncia contratual pelo juiz para demonstrar a positivação pelo Código de um entendimento jurisprudencial construído com base na prática quotidiana e da necessidade de mínima segurança jurídica para o retorno de investimento realizado por empresários. 
A tese de livre-docência apresentada ao Departamento de Direito Comercial da Faculdade de Direito da Universidade de São Paulo pela Professora Paula A. Forgioni, denominada $O$ contrato de distribuição: função econômica e análise jurídica, traz exemplo perfeito: o contrato de distribuição (e aqui menciono o contrato de distribuição como o de concessão comercial, e não aquele trazido pelo artigo 710 do Código Civil) foi reconhecido primeiramente "pela jurisprudência" como contrato típico, próprio e de execução continuada, contrariamente à argumentação abusiva de que seriam várias compras e vendas realizadas pelo mesmo intermediário. Para que assim fosse entendido pela jurisprudência, ${ }^{68}$ esta se antecipou ao artigo 473, parágrafo único, e elaborou análise da função econômica do contrato, sua natureza e o vulto dos investimentos normalmente realizados pelos distribuidores. Hoje, a jurisprudência majoritária entende que em um contrato deste por prazo indeterminado pode-se denunciar o contrato, "desde que seja feito com um prazo razoável".

Assim, o dispositivo mencionado do Código Civil, que determina que a "resilição unilateral, nos casos em que a lei expressa ou implicitamente o permita, opera mediante denúncia notificada à outra parte", porém ressalva em seu parágrafo único que, dada a natureza do contrato, se uma das partes houver feito investimentos consideráveis para a sua execução, “a denúncia unilateral só produzirá efeito depois de transcorrido prazo compatível com a natureza e o vulto dos investimentos".

Pela "natureza do contrato", a lógica leva-me a crer que, a partir da referida construção jurisprudencial, o artigo provavelmente refere-se àqueles de execução continuada, que prevejam "investimento". Neste caso, sendo prevista a "eficácia suspensa" da denúncia até que sejam recuperados os investimentos, com arbitramento a cargo do juiz, principalmente para os negócios empresariais, há de ser questionado: (i) qual o tipo de investimento a que se refere o artigo e (ii) quais serão os critérios "econômicos" para auferimento de prazos.

Os recursos de força de trabalho, know-how e formação de clientela seriam passíveis de ser considerados investimentos a serem recuperados mediante suspensão da denúncia? Para responder a essas e tantas outras questões sobre os tipos de investimentos e os modos de auferimento de valores e prazos, será necessário que os juízes façam análises não só jurídicas, mas principalmente mercadológicas e econômicas. Seja por perícia, seja por estudo e preparação própria ou da classe (por eventuais iniciativas de aprimoramento, comuns nas Escolas de Magistratura).

Haverá, por exemplo, necessidade de verificar se os investimentos enquadram-se como: (i) investimentos irrecuperáveis (no sentido de que o prazo deve permitir sua amortização) e (ii) recuperáveis (e aí sim definir o prazo para "recuperar o recuperável” a partir da notificação da denúncia). Se um juiz que precisa auferir o valor para embasar o prazo de continuação do contrato com base no artigo 473, de maneira temerária, opta ser por utilizar o critério de "custo de oportunidade" (assim denominado na teoria econômica), o qual significa, "grosso modo", determinar o valor que 
poderia ter sido ganho se o dinheiro estivesse investido, certamente não calculará um valor real de ressarcimento.

Contudo, trago estes questionamentos a este texto apenas para chamar atenção de que muitas vezes, em especial no âmbito da aplicação em relações empresariais, a vagueza de uma norma envolve não só uma interpretação jurídica, mas também de outras ciências, das quais os intérpretes não podem se isolar para que não cometam injustiças ou preguem "meias verdades".

\section{I.5 EXCESSIVA ONEROSIDADE}

Os artigos 478, 479 e $480^{69}$ do Código Civil prevêem a resolução dos contratos de execução continuada ou diferida, nos casos em que a prestação de uma das partes se tornar excessivamente onerosa, com extrema vantagem para a outra, em virtude de acontecimentos extraordinários e imprevisíveis, salvo se o demandado oferecer modificação contratual para tornar as condições eqüitativas.

Muito do que já foi exposto sobre racionalidade empresarial nos quatro exemplos acima pode ser aplicado a estes dispositivos. O Código Civil menciona “acontecimentos extraordinários e imprevisíveis", mas a doutrina e a jurisprudência protegem os contratos empresariais da fragilidade pelo entendimento de que as condições de mensuração da eqüidade voltam-se para a função econômica do contrato e, especialmente, porque, para auferir o "extraordinário e imprevisível" nas relações empresariais, os padrões são embasados nas condutas de empresários, que atuam em seus mercados específicos (diferente do cidadão comum ou do consumidor e seus contextos de vida).

Assim, não há dúvida na doutrina e na jurisprudência - e não há de havê-la após a promulgação do Código - de que, nos casos em que a desvantagem advém da álea normal do negócio, de acordo com a natureza do contrato (moldura), não há que falar em excessiva onerosidade.

Novamente afirmo que, no ambiente do Direito Empresarial, o agente que "erra" a jogada continuará a ser - como sempre foi - penalizado pelo mercado.

\section{TENDÊNCIA DE AMPLIAÇÃo DOS PODERES DO JUIZ TAMbÉm eXPRESSA no Direito Processual}

A gênese do Estado de Direito, no final do século XVIII, início do XIX, vem evidentemente inspirada pela ideologia liberal, em que prevaleciam o individualismo (e a intangibilidade das garantias do indivíduo em relação ao poder estatal, especialmente no tocante ao direito de propriedade, da autonomia da vontade e da livre iniciativa) e a igualdade formal de todos perante a lei. Esses ideais ficaram por longo tempo impregnados na consciência jurídica daqueles que operam o Direito, e somente hoje é que se sente, no Brasil, efetivamente, a superação 
desses paradigmas. ${ }^{70}$ Como visto nos itens anteriores, são vários os indícios dessa mudança de mentalidade.

De fato, se no terreno contratual "instituiu-se"71 no Direito Privado o princípio da boa-fé objetiva como regra interpretativa que permite ao juiz afrouxar os laços obrigacionais que emergiam da vontade esposada pelos contratantes, é porque se criou a consciência de que a autonomia da vontade não é nem pode ser ilimitada.

Somam-se a tudo isso grandes mudanças de perspectiva de análise jurídica, como o reconhecimento da função social da propriedade e dos contratos, até a instituição de regras de atenuação do princípio do pacta sunt servanda, como as regras concernentes à lesão nas relações civis, ao estado de perigo e à onerosidade excessiva.

Mesmo saindo do campo empresarial, o que mais interessa a este trabalho, a especialização e desenvolvimento das regras de defesa do consumidor só foram possíveis porque se quebrou o princípio da igualdade formal de todos perante a lei.

Esses são apenas alguns sinais que denotam uma superação do ideal liberal, que vinha impregnado no Código Civil de 1916, e que vinham sendo dados na jurisprudência muito antes da entrada em vigor do novo Código. Ou seja: não se tratou de um processo rápido e que se consubstanciou em uma reforma legislativa; ao contrário, foi ele longo e paulatino.

Com efeito, muitas das regras que, hoje, estão expressas no direito positivo já vinham sendo aplicadas pelos tribunais, ${ }^{72}$ provando que o Direito, enquanto produto da cultura humana, jamais se dissocia dos aspectos sociais e econômicos que o cercam. E mais: todas essas transformações só se operaram aumentando os poderes do juiz, pela instituição de várias cláusulas gerais e "conceitos legais indeterminados", tornando a atividade do juiz muito mais ampla no momento de interpretar/aplicar o direito objetivo, mas não só quanto às normas que regem a relação entre os indivíduos em sociedade é que essa mudança de enfoque se mostra presente.

Concomitantemente a elas, as normas que regem o processo também passaram a se adequar à superação dos ideais liberais nos quais o Código de Processo Civil de 1973 continuava a vir calcado. Apesar de ter se proclamado um diploma mais avançado, sob esse ponto de vista, do o que o antecedeu, o Código de Processo Civil projetado por Alfredo Buzaid apresentou apenas um refinamento técnico muito superior, sem ter alterado a substância das normas e a estrutura do processo estatuído pelo diploma de 1939 .

Na famosa obra Acesso à justiça, Cappelletti e Garth ${ }^{73}$ identificaram as três “ondas" de renovação do processo civil, desde os momentos vetustos em que a ciência processual passou a se afirmar como ciência autônoma.

Na primeira onda, criou-se a consciência da necessidade de alargar as portas do Judiciário para aqueles que, principalmente por deficiências econômicas e culturais, não tinham condições de ser protagonistas da solução judicial de conflitos. Um dos principais resultados dessa onda de renovação consistiu na criação de leis que 
isentavam os pobres de custas judiciais ou lhes franqueava assistência jurídica ou judiciária. Nada mais do que o reconhecimento da desigualdade entre os membros da sociedade e a aplicação da idéia de que os desiguais devem ser tratados de modo desigual, na medida de suas desigualdades.

Na segunda onda, alargou-se a proteção jurídica não só aos direitos individuais, mas também aos transindividuais, como produto do desenvolvimento da "sociedade de massa”. Assim, aumentou-se a participação do particular na defesa dos interesses compartilhados por coletividades, nas três categorias abrangidas por nossa atual legislação (isto é, o Código de Defesa do Consumidor e a Lei de Ação Civil Pública): os direitos difusos (aqueles que tocam indistintamente a todos os membros da coletividade, como o meio ambiente ou o patrimônio cultural ou urbanístico); os coletivos (aqueles compartilhados por um grupo de pessoas que estão ligadas por uma relação jurídica base, como todos os membros de um sindicato ou todos os empregados de uma determinada empresa); e, finalmente, os individuais homogêneos (os compartilhados por um grupo indistinto de pessoas e que, embora possam ser reclamados individual e separadamente por cada um dos interessados, podem ser defendidos em conjunto pelos entes legitimados pela lei).

A terceira e última onda - que, pode-se dizer, vem sendo implementada em nosso ordenamento, ao contrário das outras já superadas por nós - é marcada por uma série de medidas que implementem a realização do acesso à justiça por meio do processo, que vão desde a especialização dos juízes até o incremento dos seus poderes de iniciativa probatória, o aumento da importância da mediação e da conciliação etc.

De fato, o movimento reformista a que se deu início logo após a promulgação da Constituição Federal de 1988 resultou em uma completa transformação do processo, especialmente em duas searas.

A primeira delas está centrada no aumento dos poderes do juiz na condução da causa, seja pelo alargamento da possibilidade de sua iniciativa probatória, seja pelo aumento dos seus poderes na coibição da litigância de má-fé e do abuso dos direitos processuais. Coloca-se, assim, o juiz como autoridade pública, protagonista principal do processo e condutor desse instrumento que deve atender a três escopos (segundo clássica obra de Cândido Dinamarco, $A$ instrumentalidade do processo): o escopo social (consistente na pacificação da comunidade por meio da eliminação dos litígios que nela surgem), o escopo político (no sentido de afirmação do Estado de Direito, por meio do juiz) e o escopo jurídico (com a aplicação do Direito Positivo aos litígios, de maneira a compô-los).

De outro lado, verifica-se um aumento da "efetividade dos instrumentos de cumprimento" das decisões judiciais. Aqui, novamente, as modificações dividem-se em duas ordens.

A primeira ordem de modificações nesse sentido operou-se via generalização das antecipações de tutela, a fim de impedir que aquele que razoavelmente demonstre 
ter direito não se prejudique por causa do "garantismo" exagerado dos direitos do réu, e o provimento final do processo, que reconheça o direito reclamado pelo autor, lhe seja inútil, pois o resultado prático que esperaria do provimento jurisdicional já não mais lhe serve. ${ }^{74}$ Superou-se, assim, a insuficiência do processo cautelar como meio de "preservar" determinada situação jurídica, de modo a deixá-la em compasso de espera até que o processo chegasse à sua solução final, somente quando se poderiam sentir, realmente, os efeitos práticos da decisão jurisdicional.

A segunda ordem de alterações diz respeito aos instrumentos para assegurar o "cumprimento" das decisões judiciais, com a completa desfiguração do processo de "execução", principalmente. As primeiras modalidades de execução atingidas foram as das obrigações de fazer e não fazer, com a reforma, em 1994, do artigo 461 do Código de Processo Civil. O que chama a atenção, aqui, é a prevalência da "execução específica” das obrigações e dos comandos emergentes da decisão judicial. Anteriormente, sob os cânones da ideologia liberal, a vontade humana era intangível, de maneira que o descumprimento a um dever de fazer ou não fazer redundava invariavelmente na conversão em perdas e danos. Hoje, ao contrário, privilegia-se sempre o cumprimento específico das obrigações, com a implementação de uma série de "meios de apoio" tendentes a "coagir" o litigante a adimplir o seu dever.

Destacam-se, aqui, especialmente as "astreintes" (ou as também chamadas "multas cominatórias"), mas não se resumem a elas, pois ao juiz é franqueado determinar "todas as providências necessárias para que a sentença seja cumprida". Haveria uma "atipicidade" dos meios de apoio, que poderiam adequar-se ao caso concreto e incluir busca e apreensão de pessoas e coisas, desfazimento de obra, uso de força policial etc. Todos esses meios são empregados ou como mecanismos de coerção (impelem o devedor a comportar-se de determinada forma para evitar as conseqüências negativas do seu inadimplemento) ou de sub-rogação (substituição da vontade do devedor pelo ato judicial, que determinará, por meio de seus auxiliares, que faça aquilo que a parte deixou de fazer).

Depois, esses mesmos mecanismos de enforcement das decisões judiciais estenderam-se também àquelas que impunham obrigação de dar, o que se consubstanciou na introdução do artigo 461-A no Código de Processo Civil, em 2002. Outras reformas se avizinham, agora com o objetivo de tornar mais efetiva a execução de obrigações de pagar quantia em dinheiro.

Cabe apenas abrir parênteses para observar que o Código Civil atual, promulgado em 2002, não atentou para essas transformações e dispôs, em seus artigos 249 a 251, que a inobservância dos deveres de fazer, não fazer e dar redundam sempre em conversão da obrigação em pecúnia. Trata-se, de fato, de um retrocesso em relação às reformas recentes no sistema processual, e seus efeitos podem ser devastadores se pensarmos que o Código Civil entrou em vigor depois das alterações nos artigos 461 e 461-A do Código de Processo Civil e, tratando-se de leis ordinárias, prevalece a posterior. 
Deixando de lado essa questão, o espírito que norteia essas duas esferas de transformações não é outro, senão o de implementar o processo como meio "efetivo" de acesso à justiça (ou, segundo a expressão cunhada por Watanabe (2000) e largamente disseminada, “acesso à ordem jurídica justa”), isto é, um meio de implementação de direitos.

A ferramenta indispensável para tanto é, justamente - e aqui retornamos a um dos pontos iniciais -, o aumento dos poderes do juiz. Não pode mais ele, como autoridade estatal encarregada da pacificação social com justiça, adotar postura passiva diante do conflito. Seu ativismo deve ser incentivado como condição indispensável para a realização do Direito.

É justamente nessa perspectiva que emerge a importância da "criação jurisprudencial” também na órbita do processo.

Com efeito, nada mais além do empenho dos juízes em tornar o processo um meio efetivo de realização do Direito, explica criações pretorianas como a penhora de faturamento (limitada, segundo assentaram inúmeros julgados, ao percentual de 30\%), em substituição ao instituto do "usufruto de empresa" (artigos 671 e seguintes do Código de Processo Civil), de dificílima e raríssima aplicação.

Assim, seja no campo do Direito Processual, seja no campo do Direito Privado, a complexidade crescente dos conflitos que surgem na sociedade gera a necessidade de interpretação casuística para que estes sejam satisfatoriamente solucionados. Uma vez que o sistema positivo nunca preverá todas as situações de fato e para garantir a completude do sistema jurídico - único e uno - a jurisprudência aplica as leis, ou seja, interpreta-as de forma a garantir a "justiça" por meio das decisões que a formam.

Essas decisões, de maneira conjunta, por vezes geram positivação de suas tendências e entendimentos (vide exemplo da denúncia unilateral supra), outras vezes trazem diferentes "sentidos" a normas já positivadas (vide acima a menção às diferentes aplicações de cláusulas gerais nos Direitos Civil e Comercial). De qualquer forma, a jurisprudência garante (i) a aplicação concreta das normas aos conflitos e (ii) a previsibilidade de interpretação daquelas normas que ainda precisam de "sedimentação" no sistema.

Observando a doutrina e a jurisprudência construída ao longo do tempo, os atores (em especial, neste trabalho, os agentes econômicos) podem prever suas decisões futuras, tendo em vista que serão fundamentadas em novos dispositivos legais, "mas nem sempre em novo direito". 75 Da mesma forma que se pode fazer "direito novo" a partir de regras velhas ${ }^{76}$ pela interpretação contextualizada e contemporânea, manter-se-ão o "velho Direito Comercial” e suas práticas, após a promulgação de novas regras de Direito Privado unificadas pelo Código Civil de 2002. 


\section{NOTAS}

1 Pesquisadora da Direito GV. Doutora pela Faculdade de Direito da Universidade de São Paulo.

2 Sobre o significado de jurisprudência de acordo com o entendimento mencionado vide Montoro (1977), conforme os trechos abaixo transcritos:

"A palavra jurisprudência pode ter, na linguagem jurídica, três significações diferentes:

1. pode indicar a Ciência do Direito, em sentido estrito, também denominada Dogmática Jurídica ou Jurisprudência; 2. pode referir-se ao conjunto de sentenças dos Tribunais, em sentido amplo, e abranger tanto a jurisprudência uniforme como a contraditória; 3. em sentido estrito, jurisprudência é apenas o conjunto de sentenças uniformes; nesse sentido, falamos em firmar jurisprudência ou contrariar a jurisprudência.

É nesta última acepção que se coloca o problema da jurisprudência como fonte de direito. [...]

Jurisprudência não se confunde com sentença. Sentença é uma decisão individualizada, aplicável a um caso concreto. Enquanto que a jurisprudência, como fonte de direito, constitui uma norma geral, aplicável a todos os casos idênticos. Da mesma forma que o costume se forma pela repetição de fatos individuais, a jurisprudência se constitui através de sentenças idênticas. Daí a aproximação que muitos autores fazer entre a jurisprudência e o costume. Alguns chegam mesmo a denominá-la costume judiciário, em oposição ao costume popular”.

3 Para Mancuso (2001), a "palavra jurisprudência não apresenta um conteúdo unívoco, ao longo da evolução do Direito, no tempo e no espaço" (p. 19) e ensina que cinco são as acepções para a "visualização da jurisprudência”: a) no sentido amplo de "ciência do Direito"; b) etimologicamente, como o "Direito aplicado aos casos concretos pelos hoje denominados operadores do Direito; c) sob o ângulo exegético, ou hermenêutico", como "interpretação teórica do Direito, feita pelos jurisconsultos e doutrinadores (juristas) em artigos, teses, livros ou mesmo em pareceres, sem, portanto, necessária afetação a um caso concreto; d) sob o ângulo da distribuição da justiça", como a "somatória global de julgados dos Tribunais, harmônicos ou não, ou seja, a totalização dos acórdãos produzidos pela função jurisdicional do Estado"; e pela acepção adotada neste trabalho: e) "num sentido mais restrito, ou propriamente técnico-jurídico", como a "coleção ordenada e sistematizada de acórdãos consonantes e reiterados, de um certo Tribunal, ou de uma dada Justiça, sobre um mesmo tema jurídico" (p. 32-33).

4 Dessa maneira, vê-se com clareza a complementaridade das ciências do Direito e da Economia no âmbito da interpretação das regras atinentes às obrigações contraídas no ambiente empresarial, que dá motivo a uma pesquisa própria aprofundada e a escusa da não-inclusão desta por esta autora para os limites deste trabalho, sob pena de perder o foco de análise.

5 O estudo do papel da prestação jurisdicional na diminuição do inadimplemento das obrigações e no desenvolvimento econômico, no entanto, foi empreendido por Leonardo L. Ribeiro, em seu artigo Interações medicamentosas - o papel conjunto do sistema judiciário e das medidas de âmbito privado na diminuição da inadimplência e no desenvolvimento econômico (trabalho não publicado, apresentado como monografia no curso "Obrigações e Obrigações Empresariais”, ministrado no $1 .^{\circ}$ semestre de 2004 pelo Professor Mauro Rodrigues Penteado na Pósgraduação da Faculdade de Direito da USP), o qual será apontado neste texto em algumas ocasiões para explicar algumas fundamentações que, conforme já dito, podem ser tidas como “jurídico-econômicas", na medida em que as duas áreas - a do Direito e da Economia - prestam soluções em conjunto para alguns problemas.

6 “Os princípios gerais" (tradução livre).

7 Em outras palavras, os intérpretes traduzem, ao usar a fórmula dada a definição de princípio, "de maneira mais ou menos consciente, a idéia de direito, de norma, de ordenamento, de justiça e de seu próprio papel” (tradução livre), em Alpa (1993, p. 46).

8 Segundo Paula A. Forgioni (2003, nota 34), no qual ainda ensina: "sobre a moderna teoria da interpretação e o papel nela desempenhado pelos princípios jurídicos v. Eros Roberto Grau, Ensaio e discurso sobre a interpretação/aplicação do direito, p. 122 e ss. Do mesmo professor, $O$ direito posto e o direito pressuposto, p. 46-47".

9 Sobre serem ou não conceituados os princípios como regras, vide também que, para Rosa Maria de Andrade Nery (2002, p. 110), o Direito não submete as situações de fato normalmente aos princípios, mas sim às "regras". Para a autora, não se podem classificar os princípios como regras, nem como regras gerais, já que para aplicação aos casos concretos é necessária sua concretização. Para Nelson Nery Junior (2003, p. 406), traz o vocábulo "regra” ao conceituar os princípios 
como "regras de conduta que norteiam o juiz na interpretação da norma, do ato ou negócio jurídico. Os princípios gerais de Direito não se encontram positivados no sistema normativo. São regras estáticas que carecem de concreção. Têm como função principal auxiliar o juiz no preenchimento das lacunas" (grifos nossos).

10 (ALPA, 1993, p. 6/9). Nesta obra, o autor trata de diversas noções de "princípios”, em vários contextos (ex. como elemento de disciplina, como valor, como instrumento e como regra abstrata), com funções identificadas conforme o papel do intérprete: uso doutrinário, jurisprudencial ou legislativo.

11 Em Alpa (1993, p. 9): "che appaiono sottrarre il lavoro degli interpreti ad um chiaro quadro di riferimenti e di connessioni logiche" (tradução livre).

12 O Código austríaco de 1811 foi o primeiro a prever expressamente sua existência jurídica, não positivada, em seu artigo 7. : " "...] si el caso resultase aún dudoso, se decidirá según los princípios del derecho natural, habida consideración de las circunstancias diligente recogidas y maduramente ponderadas”.

13 A exemplo da função social do contrato contida no artigo 421, a boa-fé objetiva e a probidade no contrato contidas no artigo 422; entre outras como as dispostas nos artigos 187, 2.035, 623, 1.208, 1.634, 927 do Código Civil etc.

14 Larenz-Wolf, Allg Teil, § 3. ${ }^{\circ}$, IV, n. 94, p. 82-83, apud Nelson Nery Junior (2003, p . 408).

15 Vide também Reale (2000).

16 “Conceitos legais indeterminados são palavras ou expressões indicadas na lei, de conteúdo e extensão altamente vagos, imprecisos e genéricos”, segundo Nelson Nery Junior (2003, p. 407). Vide ainda Barbosa Moreira (1979), p. 605-622.

17 Extraído de Alpa; Bessoni (2001, p. 18) (tradução livre).

18 Importante ressaltar que se utiliza do termo para especificar a necessidade de aplicação de cláusulas gerais para resolução de caso que dê ensejo a isto, mas atento para parte da doutrina que, como Alpa; Bessoni (2001, p. 18), entendem ser a expressão "ordine pubblico" equivocada em alguns casos uma vez que "non indica, quando 'e impiegata nel diritto privato, soltanto l'ordine esterno, l'ordine della coletività, in altre parole l'ordine di polizia; indica invece il complesso dei principe inderogabili sui quali si fonda l'ordinamento". Assim, segundo os mesmos autores (p. 19), as normas de ordem pública estabelecem a tutela dos interesses públicos e se relacionam com diversos tipos de relações, a exemplo da disciplina do matrimônio (família) e da nulidade de pactos de não-concorrência superiores a um determinado período de tempo, conforme o artigo 2.596 do Codice Civile (natureza econômica).

19 Vide decisão da Corte de Cassazione italiana de 1993, n. 348, bem como a de n. 6381, citadas por Alpa; Bessoni (2001, p. 19).

20 Por "não formal" quer-se dizer "não-vinculante" no mundo do dever ser, mas que se mostra vinculante na análise dos conflitos práticos da vida quotidiana, "da vida como ela é".

21 Neste sentido, vide Leonardo L. Ribeiro (não publicado, p. 6), sobre a impossibilidade de completude de leis e contratos em razão da limitação da racionalidade do ser humano e os "conseqüentes custos positivos e crescentes para se obter informação". Segundo o autor, "o reconhecimento de que os seres humanos têm sua racionalidade limitada é fundamental para que se compreenda a importância das instituições em uma sociedade. Por outro lado, como as instituições são forjadas pelo homem, também é de se esperar que a racionalidade limitada impeçam-nas de serem completas. Por exemplo, não se deve esperar que as leis sejam redigidas de forma a abarcar todo e qualquer comportamento humano. De forma análoga, o legislador não pode prever as inúmeras formas com que as patologias da inadimplência surgirão e se repetirão". Ainda, para o conceito de "instituições" da forma tratada, vide p. 3 do mesmo trabalho.

22 Conforme Grau (2003b), p. 71: "Praticamos a interpretação do direito não - ou não apenas - porque a linguagem jurídica é ambígua e imprecisa, mas porque, como adiante veremos, interpretação e aplicação do direito são uma só operação, de modo que interpretamos para aplicar o direito e, ao fazê-lo, não nos limitamos a interpretar (= compreender) os textos normativos, mas também compreendemos (= interpretamos) os fatos". 
23 Conforme Eros Roberto Grau (2003, p. 153 et seq.), aí se revela o caráter alográfico da interpretação do Direito.

24 Mais uma vez, conforme o Professor Eros Roberto Grau (2003b), p. 81.

25 Aqui se fala da "interpretação autêntica" feita pelo órgão estatal aplicador do Direito, enunciada por Kelsen, por meio da qual a interpretação cognoscitiva do Direito - advinda de operação de conhecimento - é somada ao ato de vontade em que o órgão aplicador do direito efetua uma escolha entre as possibilidades reveladas por meio daquela mesma interpretação cognoscitiva, segundo Grau (2003b, p. 86).

26 Vide ainda Marcelo Neves (2003, p. 361, nota 24): “A norma jurídica só é produzida no decurso da solução do caso" e complementa: "Nesse sentido, afirma Muller que o juiz não é 'legislador de segundo grau', mas sim o único legislador, mesmo que isso soe estranho".

27 Nas palavras de Ruiz e Cárcova (1991, p. 320).

28 Vide também Mancuso (2001, p. 28), reportando-se na nota de rodapé 36 a Lúcio Bittencourt (1998, p. 145): “A esse ponto veio ressaltado por Charles Evans Hughes, Presidente da Suprema Corte norte-americana: 'Vivemos sob uma Constituição, mas a Constituição é o que os juízes afirmam que ela é (We are under a Constitution, but the Constitution is what the judge say it is) '”.

29 "Se quanto detto fin qui è vero, è però altrettanto vero que spesso l'interpretazione data dalle corti ad una disposizione di legge possiede di fatto un'efficacia persuasiva tutt'altro che trascurabile”, Nivarra, Ricciuto e Sconamiglio, Istituzioni di diritto privato, p. 15 (tradução livre).

30 Informal e, talvez, casuística. Contudo, os elementos deste estudo fazem-me enxergá-la como fonte do Direito. A maioria da doutrina se mantém em correntes que ensinam que a norma ou regra "vem de cima", imposta pelo Estado regulador ou "de baixo", como ensinaram tantas vezes Ascarelli, Vivante, Irti e "não pelo lado", nas palavras da Professora Paula Forgioni, em relato em 13.01, significando construção jurisprudencial. No entanto, sem discordar, não se pode negar a criação da norma pelo juiz a partir do texto normativo e a segurança e certeza causada tão-somente pela análise da interpretação da norma pelos julgados, fatores que me levaram às conclusões deste trabalho, considerando o Direito como fenômeno além da regra, mas como ciência produzida pelo sistema jurídico que abarca a regra.

31 Note-se, contudo, que muitas vezes o fator econômico é aquele determinante da maior ou menor completude de um contrato celebrado, com a omissão de disposições para manter flexibilidade.

32 Ribeiro (não publicado, p. 3). Nota-se a repetição da citação deste artigo na medida em que este trabalho, em alguns momentos, dialoga com a referida monografia, não aderindo a todas as suas conclusões, mas demonstrando a utilidade da co-explicação jurídica e econômica para os mesmos problemas, de forma a tentar respondê-los de maneira mais abrangente.

33 A parcela da normatização que se terá em foco, contudo, será aquela aplicável ao Direito Comercial, que se dá tanto pelos usos como pelas regras positivadas.

Quanto aos usos, merece destaque o conceito de "bom costume", que em conjunto com o de "ordem pública" apresenta relevo particular no Direito Empresarial porque resguarda a validade dos atos jurídicos. Bom costume não é boa-fé. Esta será adiante tratada pela sua influência no adimplemento dos contratos. Não é também um complexo de princípios de ordem moral e sexual, tampouco o complexo de princípios sociais e morais que são o fundamento de uma sociedade. A noção de bom costume, como a de ordem pública, é ampla e variável de acordo com o desenvolver dos costumes ou praxe ou das condições econômicas e sociais, dentro de um certo contexto e momento histórico (Vide Alpa; Bessone, 2001, p. 19 et seq.).

Ainda sobre normatização mercantil, Eros Roberto Grau em seu discurso de agradecimento proferido na solenidade de entrega da medalha Teixeira de Freitas discorre: "O Código Civil é codificação de preceitos normativos que ordenam relações sociais entre pessoas, simplesmente. Surge quando o Estado deles se apropria, produzindo direito posto. Além deles, porém, também os preceitos aplicáveis aos que praticam atos do comércio apropria-se o Estado. Nosso Código Comercial ainda era medievo, embora consubstanciasse um tipo de "código aberto", por cujas frestas penetravam, fecundando-o, os usos e as práticas mercantis. Desses preceitos - repito - também se apropria o Estado. Mas é certo que o substrato do sistema de Direito Comercial é integrado por dois tipos de normas: (i) aquelas originárias dos próprios comerciantes, em 
sua prática, e (ii) aquelas nascidas de autoridades exógenas aos comerciantes". O autor cita, em seu apoio, em nota de rodapé, a tese de Forgioni (2002, p. 346-347).

34 Para tanto, além do "poder" de pacificar entendimentos ou transformá-los nos diversos tribunais do país, a jurisprudência conta com instrumento fortíssimo, qual seja os julgados e súmulas do Supremo Tribunal Federal brasileiro, que por diversas vezes foi invocado para colocar "pá de cal” em divergências surgidas na sociedade ou entre esta e o Estado, nas quais em diversas delas adotou fundamentos que dessem razões a necessidades políticas (econômicas ou sociais) nacionais.

35 Vide Crane (1987, p. 324-347), artigo apresentado no encontro da SPTL Administrative Law Group na Universidade de Warwick, em 23 e 24 de março de 1987. Também: Bernstein (1992, p. 115-157).

36 No mesmo discurso: "A garantia da fluência de suas relações é uma dupla garantia, contra o Estado e contra os outros agentes econômicos que atuam no mercado”. Quanto à primeira, depois, o Professor Eros Roberto Grau explica "a generalidade e a abstração da lei garantem o indivíduo contra a arbitrariedade estatal, porque isso é indispensável ao cálculo e segurança inerentes à produção capitalista; mas o cálculo e segurança inerentes à produção capitalista reclamam também previsibilidade no comportamento dos agentes econômicos". Adiante, ainda repete: “[...] Vale dizer, cálculo e segurança inerentes à produção capitalista exigem uma dupla garantia: (a) contra o Estado [= liberalismo político] e (b) em favor do mercado [= liberalismo econômico]".

37 Para definição de mercado nesse trabalho, Eros Roberto Grau (2004), palestra proferida na Universidade de Lisboa: "Ao final do século XVIII o mercado toma forma como projeto político e social e serve ao tipo de sociedade que os liberais desejavam instaurar. O mercado se desdobra: sem deixar de referir os lugares que designamos como mercado e feira, assume o caráter de idéia, lógica que reagrupa uma série de atos, de fatos e de objetos. Mercado deixa então de significar exclusivamente o lugar no qual são praticadas relações de troca, passando a expressar um projeto político, como princípio de organização social".

38 Consolidação das Leis Civis, Rio de Janeiro, Typographia Universal de Laemmert, 1885, página X da Introdução.

39 Transcrição do Instituto dos Advogados Brasileiros, 2003, p. 11

40 Rosanvallon (1989, p. 3).

41 Introdução da obra de Guido Alpa e Mario Bessone, já tantas vezes citada neste trabalho, Elementi di diritto privado, p. 4 (tradução livre)

42 Muitos destes eram originários (nascidos) de ideais socialistas, a exemplo de incentivos econômicos a famílias pobres, medidas políticas para intercâmbio e distribuição de riquezas entre as regiões italianas, a criação da previdência social, entre outras, desnaturados pelo uso da força e pela posterior aliança nazista.

43 Extraído em 10.09.2003 do texto do Professor Miguel Reale, os princípios que nortearam a elaboração do Código de 2002, são os da eticidade, socialidade e operabilidade, de forma a tornar efetiva a previsão de normas para "o homem comum" Disponível em: <http://www.miguelreale.com.br/artigos/ncc/discmr.htm>.

44 Em Ascarelli (2001, p. 93).

45 Storia universale del diritto comerciale (1913, p. 13).

46 Cabe mencionar, ainda que não se trate de transcrição, que muitos destes exemplos foram extraídos da análise realizada pela Professora Paula Andrea Forgioni, em palestra sobre Contratos e direito concorrencial, no mês de maio de 2004, na sede da Associação dos Advogados de São Paulo (AASP), em curso denominado "Contratos no Novo Código Civil”, coordenado pela Professora Priscilla Maria Pereira Correa da Fonseca.

47 Azevedo (2002, p. 152-154) explica que, à semelhança da vontade, que também não é elemento do negócio, mas é importante para sua validade e eficácia, a causa também não age no plano da existência, e sim nos outros dois mencionados. Para o autor, o papel da causa será de proteção à parte que se fiou na existência dela. Além disso, o autor distingue os dois diferentes tipos de causa entre o de "causa-motivo (como na expressão 'causa ilícita', que somente pode 
ser entendida como 'motivo determinante ilícito' [...]; o de causa-fato jurídico, causa efficiens [...] em que a causa equivale ao fato jurídico que dá origem à obrigação [...]” e o sentido que o autor diz ser predominante atualmente ao qual se denomina sentido objetivo da causa, "isto é, um terceiro sentido da palavra, pelo qual se vê na causa, a função práticosocial [para os autores que vêem causa também nos negócios patrimoniais], ou econômico-social do negócio [para os que somente levam em conta a causa dos negócios patrimoniais]", a causa entendida, pois, como "função".

48 Luca Nanni (1988), especialmente no capítulo $4 .^{\circ}$ trata com cuidado o instituto da presupposizione e atesta, na p. 402, que o artigo 1.366 c.c. é o artigo mais freqüentemente aplicado para fundamentar as sentenças que se socorrem daquele. Vale transcrever o conceito de presupposizione extraído da decisão da Corte de Cassação n. ${ }^{\circ}$ 5.168, de 22.09.1981: "Si ha presupposizione quando un determinato stato di fatto, comune ad entrambi i contrenti, il cui verificarsi sia indipendente dalla loro volontà e che abbia i caratteri dell'obiettività e certezza, sia sottinteso e deducibile dal contesto del negozio di cui costituisce il presuppostto condizionante" (p. 402), e mencionar artigo de Mario Bessone (1979, p. 403).

49 Exemplo citado pela Professora Paula Andrea Forgioni na já mencionada palestra na AASP, ao tratar de assunto similar foi a inserção de cláusulas que mitigam as vantagens e autonomia das partes, como as de exclusividade ou estoque mínimo nos contratos de concessão mercantil (distribuição), entre outros de intermediação. A “vítima”, por exemplo, da cláusula de estoque mínimo somada a outra de limitação de preço para revenda (como um concessionário de uma fábrica de automóveis) aufere vantagens suficientes e, por isso, as celebra. Contudo, se estas cláusulas passam a ser utilizadas abusivamente para achatar o lucro, por exemplo, do distribuidor, franqueador ou concessionário (já que o preço final não pode aumentar), estas deverão ser tidas como abusivas, uma vez que as condutas "fogem" da racionalidade das cláusulas celebradas e do interesse comum inicial das partes.

50 Ao tratar do consentimento no contrato, José da Silva Lisboa, o Visconde de Cayru, ensina que desde os idos de 1874, ao analisar e interpretar um negócio jurídico empresarial, há de se observar o costume ou padrão usual dos agentes no mercado, conforme suas palavras: "Este consentimento póde ser verdadeiro, seja explicito ou expresso por palavra, escripto e aceno; seja simplesmente tacito, presumido ou subentendido pela natural relação dos objectos, usos e circumstancias do trato, lugar e pessoas contrahentes [...] e a suposta ordinaria intenção das partes”, (1874, p. 470).

51 Béatrice Jaluzot (2001, p. 129), sobre as diversas formulações doutrinárias comparadas para a função do princípio da boa-fé: "Le principe de bonne foi, bien que reconnu par la doctrine est formulé le plus souvent par l'exigence de la bonne foi dans l'exécution du contrat [...]

Le droit allemand a voulu faire la distinction entre ces deux sens [directive dans l'execution du contract et une règle d'interprétation des contrats] et il est le seul à avoir inséré un principe d'interpretation du contrat en vertu de la bonne foi. Ce príncipe n'existe pas em droit français tandis que le droit japonais tout em ne l'ayant pas admis comme règle écrite, le connâit par l'intermédiare dela jurisprudence $[\ldots]$

Le principe de bonne foi dans les contrats connâit par conséquent deux grandes formulations et la régle de l'exécution de bonne foi du contrat est la principale. [...] Em second lieu, la bonne foi sert l'interpretation du contrat. Le juriste français qui lira ces quelques phrases aura certainement um élan pour dire que le droit français, tout comme le droit japonais, ne connâit pas ou a rejeté une telle règle. Pourtant le sens que les auteurs allemands donnent à cette règle n'est méconnu ni em droit français, ni em droit japonais (Section II. Le príncipe de l'interprétation du contract selon la bonne foi)".

52 Artigo. 113. Os negócios jurídicos devem ser interpretados conforme a boa-fé e os usos do lugar de sua celebração.

Artigo 187. Também comete ato ilícito o titular de um direito que, ao exercê-lo, excede manifestamente os limites impostos pelo seu fim econômico ou social, pela boa-fé ou pelos bons costumes

Artigo 422. Os contratantes são obrigados a guardar, assim na conclusão do contrato, como em sua execução, os princípios de probidade e boa-fé.

53 Segundo as lições da Profesora Paula A. Forgioni em sua palestra, não se trata aqui do que Pontes de Miranda (Tratado de direito privado, t. V, p. 264) denominou "legítima expectativa". A legítima expectativa é direito expectativo, não mera expectativa de Direito. Porque o ordenamento jurídico (de Direito Comercial) coloca aquela expectativa como suporte fático necessário à incidência da norma que dá origem ao direito subjetivo. Desta forma, o empresário, que é parte de uma relação jurídica, tem o direito subjetivo a não ter frustrada a sua legítima expectativa. Por isso esta é direito e não expectativa.

54 Segundo as lições da Profesora Paula A. Forgioni em sua palestra, não se trata aqui do que Pontes de Miranda (Tratado de direito privado, t. V, p. 264) denominou "legítima expectativa". A legítima expectativa é direito expectativo, não mera expectativa de Direito. Porque o ordenamento jurídico (de Direito Comercial) coloca aquela expectativa como suporte 
fático necessário à incidência da norma que dá origem ao direito subjetivo. Desta forma, o empresário, que é parte de uma relação jurídica, tem o direito subjetivo a não ter frustrada a sua legítima expectativa. Por isso esta é direito e não expectativa.

55 A interpretação dos negócios empresariais no novo Código Civil brasileiro, RDM 130.

56 E aproveita para frisar o que crê que nem seria necessário: "neste caso, hoje sabemos que a interpretação haveria de ser restritiva, porque se trata de uma exceção à lei geral de proteção da concorrência, conforme raciocínio que desenvolvemos com Eros Roberto Grau: Restrição à concorrência, autorização legal e seus limites. Lei n. ${ }^{\circ}$ 8.884, de 1.994, e Lei n. ${ }^{\circ}$ 6.729, de 1979 ('Lei Ferrari'), in Boletim Lationamericano de Concorrência, 5, Bélgica, 1999. Também publicado na Revista do IBRAC, 6,1999, 5, bem como na Revista Trimestral de Direito Público, 21, 1998, 107”' (grifos nossos).

57 Creio que se deva temer, também por razões macroeconômicas, a "consumerização" ou "civilização" do Direito Comercial, sob pena de, paulatinamente, isolar o País de investimentos no atual contexto de economia globalizada. Os investidores estrangeiros e pátrios são "sedentos" por minimização de riscos e certamente não se interessariam em investir em um país onde eventuais litígios sejam dirimidos por decisões judiciais que podem tanto, em um pólo, atender aos padrões globais de mercado quanto, em outro, fugir para lógicas protecionistas que só servem às relações de consumo (equilíbrio perante a hipossuficiência do consumidor).

58 Diz o artigo: "Ocorre a lesão quando uma pessoa, sob premente necessidade, ou por inexperiência, se obriga a prestação manifestamente desproporcional ao valor da prestação oposta. $\S 1 .^{\circ}$ Aprecia-se a desproporção das prestações segundo os valores vigentes ao tempo em que foi celebrado o negócio jurídico. § $2 .^{\circ}$ Não se decretará a anulação do negócio, se for oferecido suplemento suficiente, ou se a parte favorecida concordar com a redução do proveito".

59 Nesse sentido é que menciono as cláusulas gerais como regras que possam ser aplicadas de ofício pelos juízes, ainda que algumas delas, a exemplo daquela que regulamenta e conceitua a lesão, sejam vistas como não "de ordem pública" na medida em que podem vir a gerar anulabilidades e não nulidades. Ou seja, por estar topologicamente no Código dentre os defeitos do negócio jurídico - o que parece errôneo diante da teoria das variações de discrepância entre vontade e declaração - e, por isso, dar ensejo a anulabilidade, há de se questionar se, neste caso, trata-se de regra de ordem pública, passível de aplicação de ofício pelo juiz. Sendo ou não assim conceituada, diante da natureza de diretriz que permeia sua aplicação, caberá ao juiz, independentemente de provocação das partes, aplicá-la ou não ao caso concreto litigioso apresentado.

60 A capacidade para contratar; que os contraentes procedessem de acordo com a boa-fé (conforme já escrito acima); que não faltassem as partes às condições do ajuste etc.

61 Artigo 153 do Código Civil: "Não se considera coação a ameaça do exercício normal de um direito, nem o simples temor reverencial”.

62 Conforme dados de estudos trazidos pelo artigo da revista Veja supramencionado: o Brasil apareceu em primeiro lugar num levantamento feito quanto ao perfil empreendedor de alguns países, com a marca de que um em cada oito brasileiros acaba montando um "negócio próprio". Em segundo lugar apareceram os Estados Unidos com a proporção de um em cada dez.

63 Ainda que os faturamentos (receita bruta) anuais máximos de uma microempresa ou de uma empresa de pequeno porte sejam diminutos em relação a outras estruturas empresariais, ou seja, respectivamente, $\mathrm{R} \$ 244.000,00$ (duzentos e quarenta e quatro mil reais) e R $\$ 1.200 .000,00$ (um milhão e duzentos mil reais), estas, em conjunto, representam grande "filão" das empresas nacionais e mobilizam grande soma de valores, além de exercerem função social de primeira grandeza diante do cenário econômico brasileiro. O referido "filão" representa não menos de $98 \%$ das empresas brasileiras, as quais garantem o emprego de sessenta milhões de brasileiros (dados do site do Sebrae).

64 Tanto é assim que a Constituição Federal, nos termos dos seus artigos 170, 178 e 179, assegura às microempresas e às empresas de pequeno porte tratamento jurídico diferenciado e simplificado nos campos administrativo, tributário, previdenciário, trabalhista, creditício e de desenvolvimento empresarial. Este preceito foi regulamento, mais recentemente, pelas Leis 9.841/1999 e $\mathrm{n}^{0}$ 9.317/1996, e algumas alterações posteriores. Por meio destas, revogaram-se as Leis 7.256, de 27.11.1984, e 8.864, de 28.03.1994.

65 A "margem de manobra" das micro e pequenas empresas é muito menor dentro do mercado - que "esmaga" a competitividade destas. Ainda que a pequena empresa nem sempre seja vista com bons olhos, uma vez que pode apresentar 
ameaça à empresa de médio porte, existe grande preocupação com a garantia da viabilidade de empresas nessa escala empresarial, que já contam com entraves quanto à obtenção de crédito para seu desenvolvimento.

66 Importante notar também, em razão da razoabilidade da interpretação no contexto em que se apresenta a disciplina do "erro" no Código, que o "erro de cálculo" mencionado no artigo 143 deve ser entendido no seu sentido estrito de erro matemático de valor a ser apresentado em contrato, e não pode ser entendido como erro de cálculo de risco da contratação, mesmo porque o artigo apenas autoriza a "retificação da declaração da vontade".

67 Mota Pinto (1999, p. 505). Vide, ainda, p. 464, a diferença entre erro-obstáculo, em que o "declarante emite a declaração divergente da vontade real, sem ter consciência dessa falta de coincidência" e a dita "falta de consciência na declaração", em que o "declarante emite uma declaração, sem sequer ter a consciência [a vontade] de fazer a declaração negocial, podendo até faltar completamente a vontade de agir”.

68 Conforme se extrai dos artigos 145 e 147 do Código Civil.

69 Vide levantamento jurisprudencial completo Forgioni (2002).

70 Art. 478. Nos contratos de execução continuada ou diferida, se a prestação de uma das partes se tornar excessivamente onerosa, com extrema vantagem para a outra, em virtude de acontecimentos extraordinários e imprevisíveis, poderá o devedor pedir a resolução do contrato. Os efeitos da sentença que a decretar retroagirão à data da citação.

71 Vide Kuhn (2001) quanto à mudança de visão que exige a alteração de pensamento e, via de conseqüência, de demandas de toda uma comunidade, desatreladas do paradigma anterior, posteriormente a uma situação de crise estrutural que faz com que aquele anterior não mais se preste às respostas a que se propõe.

72 Vide comentários ao artigo 131 do Código Comercial acima.

73 Cruz e Tucci (2003, p. 281-286) faz referência a inúmeros exemplos dessa antecipação do precedente judicial à lei, como o reconhecimento de direitos entre “concubinos", a aplicação do princípio da boa fé objetiva, do enriquecimento sem causa etc.

74 Tradução de Ellen Gracie Northfleet.

75 Na mesma esteira, Nicolò Trocker, em sua obra El derecho a un proceso sin dilaciones indebidas, p. 213 (apud Cruz e Tucci, 1997, p. 114), também observou que uma justiça obtida de forma lenta é um grande malefício à sociedade, eis que "provoca danos econômicos (imobilizando bens e capitais), favorece a especulação e a insolvência, acentua a discriminação entre os que têm a possibilidade de esperar e aqueles que, esperando, tudo têm a perder. Um processo que perdura por longo tempo transforma-se também num cômodo instrumento de ameaça e pressão, uma arma formidável nas mãos dos mais fortes para ditar ao adversário as condições da rendição”.

76 Professor Antonio Angarita, em Os óbices da Administração Estadual (reprodução da palestra do autor): "Primeira reflexão que eu propus: cuidado para nós não fazermos uma marcha errada ao desentravar; o carro pode descer pela ladeira. Depois, não é proibido criar direito novo em cima de norma velha, eu sei que é difícil, mas para isso os nossos juristas já têm tradição e os nossos juízes já têm coragem”.

77 Como as decisões dos Tribunais embasadas na necessidade de recuperação de empresas em crise a partir de interpretação contemporânea do obsoleto Decreto de 1945, a "Lei de Falências".

\section{REFERÊNCIAS BIBLIOGRÁFICAS}

ALPA, Guido et al. Interpretazone giuridica e analisi economica, Milano, Giuffrè, 1982. I I principi generali. Milano: Giuffrè, 1993. 
ALPA, Guido; BESSONE, Mario. Elementi di diritto privato. Roma: Laterza, 2001.

ANGARITA, Antonio. Os óbices da Administração Estadual. In: WALD, Arnoldo (Coord.). O direito brasileiro e os desafios da economia globalizada. Rio de Janeiro: América Jurídica, 2003.

ASCARELLI, Tullio. Panorama do direito comercial. São Paulo: Saraiva, 1947.

. O contrato plurilateral. in Problemas das sociedades anônimas e direito comparado. Campinas:

Bookseller, 2001. p. 93.

AZEVEDO, Antonio Junqueira. Negócio jurídico: existência, validade e eficácia. 4. ed. atual. São Paulo: Saraiva, 2002.

BARBOSA MOREIRA, José Carlos. Regras de experiência e conceitos juridicamente indeterminados. Estudos em homenagem ao professor Orlando Gomes. Organização da Faculdade de Direito da Universidade Federal da Bahia. Rio de Janeiro: Forense, 1979. p. 605-622.

BARROS MONTEIRO, Washington de. Curso de direito civil. 22. ed. São Paulo: Saraiva, 1983. v. 1.

BERGEL, Jean-Louis. Teoria geral do direito. Tradução de Maria Ermantina Galvão. São Paulo: Martins Fontes, 2001 .

BERNSTEIN, Lisa. Opting out of the legal system: extralegal contractual relations in the diamond industry. Journal of Legal Studies, University of Chicago, v. 21, p. 115-157, jan. 1992.

BESSONE, Mario. Presupposizione, 'causa' tipica del negozio, economia del contratto. Riv. Dir. Comm., v. 2, p. 146-403, 1979.

BITTENCOURT, Lúcio. Sobre a jurisprudência. Revista da Faculdade de Direito da Universidade Federal do Ceará. p. 145 , jul.-dez de 1998

BULGARELLI, Waldírio. Contratos mercantis. 14. ed. São Paulo: Atlas, 2001.

CAMARGO, Ricardo Antônio Lucas Camargo. Ordem jurídico-econômica e trabalho. Porto Alegre: Fabris, 1998.

CAMPILONGO, Celso Fernandes. Política, sistema jurídico e decisão judicial. São Paulo: Max Limonad, 2002.

CAPPELLETTI, Mauro; GARTH, Brian. Acesso à justiça. Trad. de Ellen Gracie Northfleet. Porto Alegre:

Fabris, 1988 .

CHIOVENDA, Giuseppe. Istituzioni di diritto processuale civile. Napoli: Jovene, 1933, v. 1.

COMPARATO, Fabio Konder. Aspectos jurídicos da macro-emprêsa. São Paulo: RT, 1970.

COSTA, Mario Julio de Almeida. Direito das obrigações. 6. ed. Coimbra: Almedina, 1994.

CRANE, Peter. Self Regulation and Judicial Review, p. 324-347. Artigo apresentado no encontro da SPTL

Administrative Law Group na Universidade de Warwick, em 23 e 24 de março de 1987.

CRUZ E TUCCI, José Rogério. Perspectiva histórica do precedente judicial como fonte do direito. 2003. Tese

(Titularidade da Cadeira de História do Direito Departamento de Direito Civil) - Faculdade de Direito da Universidade de São Paulo, São Paulo. - Tempo e processo. São Paulo: RT, 1997.

DINAMARCO, Cândido Rangel. A instrumentalidade do processo. 8. ed. São Paulo: Malheiros, 2000.

FERRI, Giovanni B. Il negozio giuridico. Padova: Cedam, 2001.

FORGIONI, Paula. A interpretação dos negócios empresariais no novo Código Civil brasileiro. Revista de Direito Mercantil Industrial, Econômico e Financeiro, 130, 2003, p. 7-38.

O contrato de distribuição: função econômica e análise jurídica. 2002. Tese (Livre-docência) - Faculdade de Direito da USP, São Paulo.

FRANCO MONTORO, André. Introdução à ciência do direito. 6. ed. São Paulo: RT, 1977. v. 2.

FRIEDRICH, Carl J. O interêsse público. Tradução de Edílson Alkmin Cunha. Rio de Janeiro, 1967.

GALGANO, Francesco. Lex Mercatoria. Bologna: Il Mulino, 2001.

GOLDSCHMIDT, Levin. Storia universale del diritto commerciale. Turim: UTET, 1913.

GRAU, Eros Roberto. A ordem econômica na Constituição de 1988 (interpretação crítica). 8. ed. São Paulo:

Malheiros, 2003a.

- Ensaio e discurso sobre a interpretação/aplicação do direito. 2. ed. São Paulo: Malheiros, 2003b.

O direito posto e pressuposto. São Paulo : Malheiros, 2003.

Mercado, Estado e Constituição. São Paulo: Renovar, 2004.

— et al. Desenvolvimento econômico e intervenção do Estado na ordem constitucional. Estudos jurídicos em homenagem ao Prof.Washington Peluso Albino de Souza. Porto Alegre: Fabris, 1995.

JALUZOT, Béatrice. La bonne foi dans les contrats: étude comparative de droit français, allemand et japonais. Paris: Dalloz, 2001.

KUHN, Thomas. A estrutura das revoluções científicas. 6. ed. São Paulo: Perspectiva, 2001.

LANZANA, Antonio Evaristo Teixeira. Economia brasileira. 2. ed. São Paulo: Atlas, 2002.

LANZILLO, Rafaella. La proporzione fra le prestazioni contrattuali. Padova: Cedam, 2003.

LARENZ, Karl. Derecho civil: parte general. Tradução espanhola de Miguel Izquierdo e Macías-Picavea. Madrid: Edersa, 1978. 
LISBOA, José da Silva. Principios de direito mercantil e Leis da Marinha. Rio de Janeiro: Typographia Acadêmica, 1874. t. II.

MANCUSO, Rodolfo de Camargo. Divergência jurisprudencial e súmula vinculante. 2. ed. São Paulo: RT, 2001. MARTINS-COSTA, Judith. A boa-fé no direito privado: sistema e tópica no processo obrigacional. 1. ed. 2. ${ }^{a}$ tiragem. São Paulo: RT, 2000.

. As cláusulas gerais como fatores de mobilidade do sistema jurídico. RT 680/50.

MOTA PINTO, Carlos Alberto da. Teoria geral do direito civil. 3. ed. 12. ${ }^{a}$ reimpressão. Coimbra: Coimbra Editora, 1999.

NANNI, Luca. La buona fede contrattuale. Padova: Cedam, 1988.

NEVES, Marcelo. A interpretação jurídica no Estado Democrático de Direito. In: GRAU, Eros Roberto;

GUERRA FILHO, Willis Santiago (Org.). Direito constitucional: estudos em homenagem a Paulo Bonavides. 1. ed. 2. ${ }^{a}$ tiragem. São Paulo: Malheiros, 2003.

NERY JUNIOR, Nelson. Contratos no Código Civil: apontamentos gerais. O novo Código Civil. Estudos em homenagem ao Professor Miguel Reale. São Paulo: LTr, 2003. p. 406.

NERY, Rosa Maria de Andrade. Noções preliminares de direito civil. São Paulo: RT, 2002. p. 110.

NIVARRA, Luca; RICCIUTO, Vincenzo; SCONAMIGLIO, Cláudio. Istituzioni di diritto privato. 2. ed. Torino:

G. Gappichelli, 2003.

OST, François. Júpiter, Hércules, Hermes: tres modelos de juez. Cuadernos de Filosofía del Derecho, Barcelona: Doxa, n. 14, p. 169-194, 1993.

PEREIRA, Caio Mário da Silva. Lesão nos contratos. 6. ed. Rio de Janeiro: Forense, 2001.

REALE, Miguel. Lições preliminares de direito - teoria tridimensional do direito: norma, fato e valor. São Paulo: Saraiva, 2000.

RIBEIRO, Leonardo L. Interações medicamentosas - o papel conjunto do sistema judiciário e das medidas de âmbito privado na diminuição da inadimplência e no desenvolvimento econômico. Não publicado.

ROSANVALlON, Pierre. Le libéralisme économique - Histoire de l'idée de marche. Paris: Éditions du Soleil, 1989. p. 3.

RUIZ, Alicia; CÁRCOVA, Carlos. Derecho y transición democrática. Materiales para una teoría crítica del derecho. Buenos Aires: Abeledo-Perrot, 1991. p. 320.

WATANABE, Kazuo. Da cognição no processo civil. Campinas: Bookseller, 2000.

WEBER, Max. Economía y sociedad. Tradução de José Medina Echeverria e outros. México: Fondo de Cultura Económica, 1969. v. 1.

WEINBERG, Mônica; BRASIL, Sandra. O segundo vestibular. Revista Veja.São Paulo,ano 36, ed. 1833, p. 168, 17 dez. 2003.

WILLIAMSON, Oliver E. The mecanisms of governance. Oxford: Oxford University Press, 1996.

DIREITO GV

Rua Rocha, $220-$ cj. 21 C

Bela vista - 01330-000

São Paulo, Brasil

ligia. pintolafgr.br
Ligia Paula Pires Pinto Sica

DOUTORA EM DIREITO PELA USP, BRASIL

Pesquisadora da direito gV, Brasil 